\title{
TITLE:
}

\section{Copepoda Associated with Crinoid Echinoderms in the Western Pacific}

$\operatorname{AUTHOR}(S):$

Humes, Arthur G.

\section{CITATION:}

Humes, Arthur G.. Copepoda Associated with Crinoid Echinoderms in the Western Pacific. PUBLICATIONS OF THE SETO MARINE BIOLOGICAL LABORATORY 1987, 32(1-3): 63-108

ISSUE DATE:

1987-08-10

URL:

http://hdl.handle.net/2433/176134

RIGHT: 


\title{
Copepoda Associated with Crinoid Echinoderms in the Western Pacific
}

\author{
By \\ Arthur G. Humes \\ Boston University Marine Program, Marine Biological Laboratory, \\ Woods Hole, Massachusetts, U.S.A. 02543
}

With Text-figures $1-22$

\begin{abstract}
Ten species of copepods are reported from crinoids in the Philippines, the Moluccas, and northern Australia. Siphonostomatoida (Asterocheridae) include seven new species of Collocheres: comanthiphilus, titillator, serrulatus, inflatiseta, parvus, thysanotus, and marginatus, and two new species of a new genus, Glyptocheres: extrusus and comanthinae. Glyptocheres may be recognized by the conspicuous posterolateral processes on the genital segment of the female and on the first postgenital segment of the male. Poecilostomatoida (Pseudanthessiidae) are represented by Pseudanthessius comanthi Humes, 1972. Crinoids (Comasteridae) serving as hosts are: Comanthus bennetti, Comanthus samoanus, Comanthus parvicirrus, Comanthus briareus, and Comanthus sp.; Comaster gracilis and Comaster multibrachiatus; Comantheria rotula; and Comanthina variabilis and Comanthina schlegeli.
\end{abstract}

Like other groups of echinoderms, crinoids have numerous copepod associates (see list given later). Most of these copepods appear to live externally on the crinoids (for example, Pseudanthessius, Collocheres), although a few live internally in the intestine (Enterognathus). The crinoid hosts reported here belong to four genera in the family Comasteridae, members of which commonly occur in shallow water throughout the tropical and subtropical western Pacific.

Only two copepods from crinoids in the vast area of the western Pacific have been reported: Pseudanthessius comanthi Humes, 1972, from Comanthus bennetti (J. Müller) at Enewetak Atoll in the Marshall Islands, and Collocheres inaequalis Ho, 1982, from Comanthus japonicus (J. Müller) in Japan. From various crinoid hosts nine new copepods are here described. These include seven new species of Collocheres and two new species of the new genus Glyptocheres.

The new copepods described here were recovered by washing the crinoids, isolated individually at the time of collection in plastic bags, in sea water to which a small amount of ethyl alcohol was added to make approximately a $5 \%$ solution. The wash water was passed through a fine net (about 120 holes per $2.5 \mathrm{~cm}$ ) and the copepods picked from the sediment retained.

The copepods were studied using the wooden slide/lactic acid technique described by Humes \& Gooding (1964). Measurements were made on specimens cleared in lactic acid. The length of the body does not include the setae on the caudal rami. In the spine and setal formulas, Roman numerals represent spines, Arabic numerals indicate setae. All figures were drawn with the aid of a camera lucida. The letter after the explanation of each figure refers to the scale at which it was

Publ. Seto Mar. Biol. Lab., 32(1/3), 63-108, 1987.

(Article 2) 
drawn. The abbreviations used are: $A_{1}=$ first antenna, $A_{2}=$ second antenna, $\mathbf{M X}_{2}=$ second maxilla, $\mathrm{MXPD}=$ maxilliped, and $\mathrm{P}_{1}=\operatorname{leg} 1$.

Identification of crinoid hosts. Many Indo-Pacific comasterid crinoids are misidentified or misunderstood species, and identifications in the monographs of A.H. Clark (1909, 1931) and in A.M. Clark \& Rowe (1971) are erroneous (F.W.E. Rowe, personal communication). Recent studies on comasterids in the Indo-Pacific including Australia (Hoggett \& Rowe, 1986; Rowe et al., 1986), have shown that the following changes in host names reported herein are necessary:

Comantheria briareus (Bell)

Comantheria rotula A.H. Clark

Comanthina belli (P.H. Carpenter)

Comanthina schlegeli (P.H. Carpenter)

Comanthus bennetti (J. Müller)

Comanthus parvicirrus (J. Müller)

Comanthus samoanus A.H. Clark
Comantheria briareus (Bell), but quite as

likely to have been for $C$. alternans

(Carpenter).

=Comantheria briareus (Bell), but rotula could be a name applied to misidentified species.

Comanthina variabilis (Bell), endemic to northwestern Australia; specimens from the Philippines suspect identifications.

valid species but may be Comanthina nobilis

(P.H. Carpenter).

Oxycomanthus bennetti (J. Müller)

The species is valid but may contain more than one species, e.g., C. gisleni Rowe et al. =Comanthus wahlbergi (J. Müller).

The following species of crinoids are valid:

Capillaster multiradiatus (Linnaeus)

Comaster gracilis (Hartlaub)

Comaster multibrachiatus (P.H. Carpenter).

In order to minimize confusion, the names of the crinoid hosts as determined by identifiers have been retained in this work. However, it must be recognized that present concepts in comasterid taxonomy, if applied, may induce name changes for some of the crinoid hosts reported here.

Order Siphonostomatoida Thorell, 1859

Family Asterocheridae Giesbrecht, 1899

Genus Collocheres Canu, 1893

\section{Collocheres comanthiphilus, new species}

(Figs 1-3)

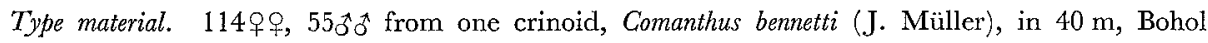
Island, Philippines, $10^{\circ} 17.9^{\prime} \mathrm{N}, 124^{\circ} 10.9^{\prime} \mathrm{E}$, 22 September 1975, Thomas Forhan collector. Holotype o, allotype, and 159 paratypes $\left(1079 \%, 52 \sigma^{-1}\right)$ deposited in the National Museum of Natural History, Smithsonian Institution, Washington, D.C.

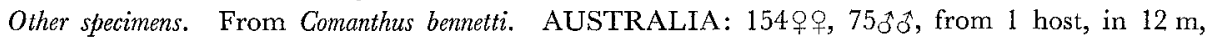
Mermaid Cove, Lizard Island, Great Barrier Reef, $14^{\circ} 39^{\prime} 50^{\prime \prime} \mathrm{S}, 145^{\circ} 27^{\prime} 00^{\prime \prime} \mathrm{E}, 26$ October 1982; 18 우, $4 \hat{5} \mathrm{o}$, from 1 host, in $12 \mathrm{~m}$, Mermaid Cove, Lizard Island, 27 October 1982. MOLUCGAS: 114 우, $85 \delta^{\circ} \delta^{\prime}$, from 3 hosts, in $4 \mathrm{~m}$, southwestern shore of Goenoeng Api, Banda Islands, $04^{\circ} 31^{\prime} 45^{\prime \prime} \mathrm{S}$,

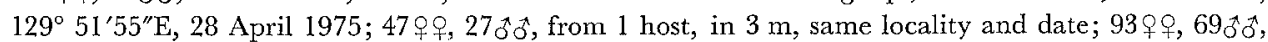
from 1 host, in $4 \mathrm{~m}$, same locality and date; $37 \% 9,21 \delta^{\circ}$, from 1 host, in $4 \mathrm{~m}$, same locality and date;

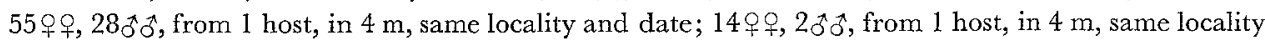

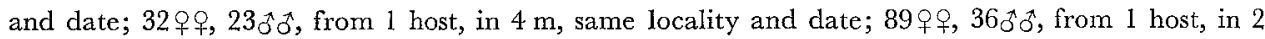




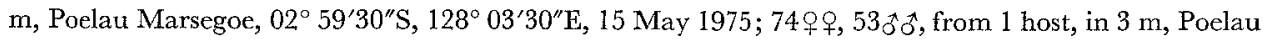
Gomumu, south of $\mathrm{Obi}, 01^{\circ} 50^{\prime} 00^{\prime \prime} \mathrm{S}, 127^{\circ} 30^{\prime} 54^{\prime \prime} \mathrm{E}, 30$ May $1975 ; 129$, $161 \jmath^{\jmath}$, from 1 host, in $3 \mathrm{~m}$, Poelau Gomumu, 30 May 1975; 32우, 56 $\delta^{\jmath}$, from 1 host, in $3 \mathrm{~m}$, Poelau Gomumu, 30 May 1975.

From Comanthus samoanus A.H. Clark. MOLUCCAS: 6우, 7ô, from 1 host, in $2 \mathrm{~m}$, Poelau Gomumu, south of Obi, $01^{\circ} 50^{\prime} 00^{\prime \prime} \mathrm{S}, 127^{\circ} 30^{\prime} 54^{\prime \prime} \mathrm{E}, 30$ May $1975 ; 1090,20^{\circ}$, from 1 host, in $25 \mathrm{~m}$, southern shore of Goenoeng Api, Banda Islands, $04^{\circ} 32^{\prime} 05^{\prime \prime} \mathrm{S}, 129^{\circ} 52^{\prime} 30^{\prime \prime} \mathrm{E}, 26$ April 1975. NEW CALEDONIA: 10 웅, $50^{\star} 0^{\star}$, from 1 host, in $0.5 \mathrm{~m}$, Ricaudy Reef, Noumea, $22^{\circ} 19^{\prime} 00^{\prime \prime} \mathrm{S}, 166^{\circ} 26^{\prime} 44^{\prime \prime} \mathrm{E}$, 5 June $197 \mathrm{I}$.

From Comanthus sp. NEW GALEDONIA: 18 우, $80^{\star} \hat{0}$, from 1 host, in $1 \mathrm{~m}$, west of Isle Mando, near Noumea, 28 July $1971 ; 84 \%$, $59 \widehat{\jmath}$, from 1 host, in $3 \mathrm{~m}$, Ricaudy Reef, near Noumea, 28 July 1971.

From ?Comanthus parvicirrus (J. Müller). NEW CALEDONIA: 2ㅇ, from 1 host, in $1.5 \mathrm{~m}$, Ricaudy Reef, near Noumea, 18 June $1971 ; 8$ 우, $60^{\star} \delta^{\star}$, from 1 host, in $5 \mathrm{~m}$, Ricaudy Reef, near Noumea, 28 July 1971.

Female. Body (Fig. la, b) slender. Length $0.73 \mathrm{~mm}(0.67-0.81 \mathrm{~mm}$ ) and greatest width $0.19 \mathrm{~mm}(0.18-0.19 \mathrm{~mm})$, based on 10 specimens. Dorsoventral thickness at level of ventral protuberance in front of first pair of legs $176 \mu \mathrm{m}$ (thickness at level of oral cone $198 \mu \mathrm{m})$. Epimeral areas of metasomal segments rounded. Ratio of length to width of prosome 2.09:1. Ratio of length of prosome to that of urosome $1.26: 1$.

Segment bearing leg 5 (Fig. 1c) $65 \times 96 \mu \mathrm{m}$. Genital segment $138 \mu \mathrm{m}$ long, $94 \mu \mathrm{m}$ wide at level of genital openings, $66 \mu \mathrm{m}$ wide in posterior third. Genital areas located at junction of anterior two thirds of segment. Each area bearing seta and small spine (Fig. 1d). Three postgenital segments from anterior to posterior $55 \times 58,39 \times 48$, and $26 \times 44 \mu \mathrm{m}$. Anal segment without sensilla on ventral surface.

Caudal ramus (Fig. 1e) elongate, $63 \times 20 \mu \mathrm{m}$, ratio 3.15:1. Outer lateral seta $38 \mu \mathrm{m}$ and dorsal seta $25 \mu \mathrm{m}$, both smooth. Outermost terminal seta $(57 \mu \mathrm{m})$ displaced subterminally, innermost terminal seta $70 \mu \mathrm{m}$, and 2 median terminal setae $117 \mu \mathrm{m}$ (outer) and $140 \mu \mathrm{m}$ (inner); all 4 terminal setae with lateral hairs. Ramus with small conical ventral terminal flange. One female with abnormal left caudal ramus as in Fig. If, right caudal ramus normal.

Body surface smooth.

Egg sac usually with 3 eggs (Fig. $1 \mathrm{~g}$ ), $230 \times 110 \mu \mathrm{m}$, egg diameter approximately $88 \mu \mathrm{m}$. One female with egg sacs having 2 eggs (Fig. 1h), sac measuring $208 \times 132$ $\mu \mathrm{m}$.

Rostral area (Fig. 1i) undeveloped. First antenna (Fig. 1j) 20-segmented, 278 $\mu \mathrm{m}$ long, not including setae. Armature: $1,2,2,2,2,2,2,2,6,2,2,2,2,2,2,2$, 2, 3+1 aesthete, 2, and 9. All setae smooth. Aesthete $68 \mu \mathrm{m}$ long.

Second antenna (Fig. 2a) $133 \mu \mathrm{m}$ long, not including terminal clawlike seta, $156 \mu \mathrm{m}$ with this seta. First segment of protopod short; second segment elongated, bearing small 1 -segmented exopod with 3 setae. Endopod with long first segment having outer setules and small second segment having small inner spine and few outer setules, and bearing long recurved clawlike terminal seta.

Oral cone prominent (Fig. 2b) in lateral view; in ventral view (Fig. 1i) with labrum rounded anteriorly and labium subtruncate posteriorly. Minute teeth on 


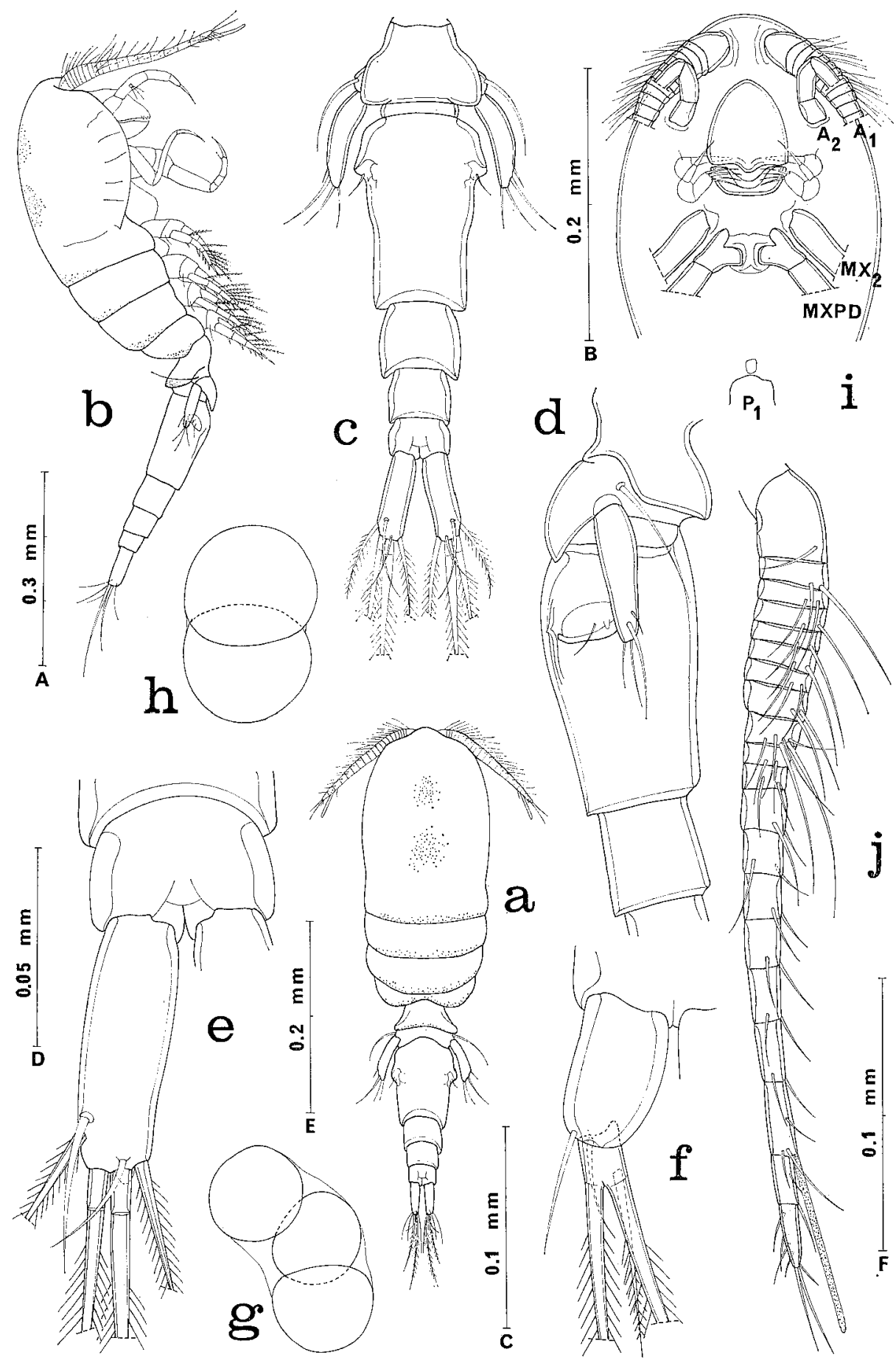

Fig. 1. Collocheres comanthiphilus, new species, female. a, dorsal (scale A); b, lateral (A); c, urosome, dorsal (B); d, segment bearing leg 5, genital segment, and first postgenital segment, lateral (C); e, anal segment and caudal ramus, dorsal (D); $f$, left caudal ramus, abnormal, dorsal (D); g, egg sac, lateral (E); h, egg sac, lateral (E); i, cephalosome, ventral (B); j, first antenna, ventral $(\mathrm{F})$. 


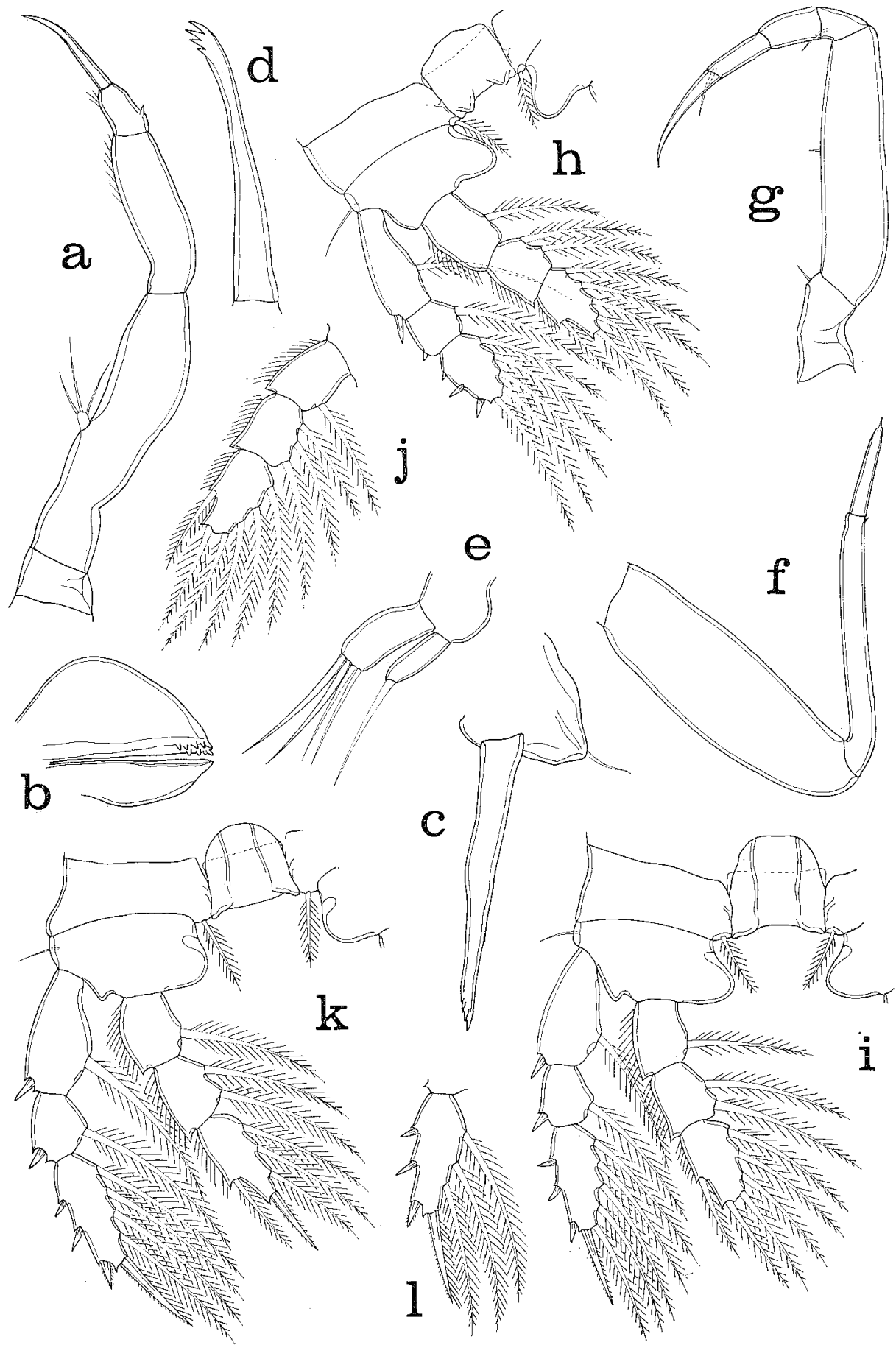

Fig. 2. Collocheres comanthiphilus, new species, female. a, second antenna, anteroventral (scale D); b, oral cone, lateral (C); c, mandible, antero-outer (D); d, blade of mandible, anterior (D); e, first maxilla, anterior (D); f, second maxilla, anterior (D); g, maxilliped, posterior (F); h, leg 1 and intercoxal plate, anterior (F); i, leg 2 and intercoxal plate, anterior (F); $j$, right endopod of leg 2, abnormal, anterior $(F) ; \mathrm{k}$, leg 3 and intercoxal plate, anterior (F); 1, third segment of left exopod of leg 3 , abnormal, anterior (F.) 
end of mandible showing at tip of oral cone between labrum and labium (Fig. 2b). Mandible (Fig. 2c) with basal part bearing slender hyaline setiform palp 15 $\mu \mathrm{m}$ long. Blade elongate, $73 \mu \mathrm{m}$ with 4 terminal teeth (Fig. 2d). First maxilla (Fig. 2e) with outer lobe having 1 seta and inner lobe 4 setae, all apparently smooth. Second maxilla (Fig. 2f) with elongate unarmed basal segment; first segment of claw slender and elongate with minute subterminal spinule, second segment only about one-third as long as first segment and bearing minute terminal filament. Maxilliped (Fig. 2g) 5-segmented. First segment with small inner distal seta. Second segment elongate and slender with minute hyaline seta about midway on inner edge. Third segment short with 1 seta. Fourth segment unarmed. Fifth segment with 1 seta. Terminal claw $39 \mu \mathrm{m}$ long.

Ventral area between maxillipeds and first pair of legs protruding as in Fig. 1b. Very small sclerite in front of intercoxal plate of leg 1.

Legs $1-4$ (Figs 2h, i, k 3a) biramous with 3-segmented rami. Spine and setal formula as follows:

\begin{tabular}{lllllllll}
$\mathrm{P}_{1}$ & coxa & $0-1$ & basis & $1-0$ & $\exp$ & $\mathrm{I}-1 ;$ & $\mathrm{I}-1 ;$ & $\mathrm{III}, 5$ \\
& & & & & $\operatorname{enp}$ & $0-1 ;$ & $0-2 ;$ & $1,2,3$ \\
$\mathrm{P}_{2}$ & coxa & $0-1$ & basis & $1-0$ & $\exp$ & $\mathrm{I}-1 ;$ & $\mathrm{I}-1 ;$ & $\mathrm{III}, \mathrm{I}, 5$ \\
& & & & & $\operatorname{enp}$ & $0-1 ;$ & $0-2 ;$ & $1,2,3$ \\
$\mathrm{P}_{3}$ & coxa & $0-1$ & basis & \multirow{2}{*}{$1-0$} & $\exp$ & $\mathrm{I}-1 ;$ & $\mathrm{I}-1 ;$ & $\mathrm{III}, \mathrm{I}, 4$ \\
& & & & & $\operatorname{enp}$ & $0-1 ;$ & $0-2 ;$ & $1, \mathrm{I}, 3$ \\
$\mathrm{P}_{4}$ & $\operatorname{coxa}$ & $0-1$ & basis & \multirow{2}{*}{$1-0$} & $\exp$ & $\mathrm{I}-1 ;$ & $\mathrm{I}-1 ;$ & $\mathrm{III}, \mathrm{I}, 3$ \\
& & & & & $\operatorname{enp}$ & $0-1 ;$ & $0-2 ;$ & $1, \mathrm{I}, 2$
\end{tabular}

Basis of leg 1 without inner seta. Outer spines on second exopod segment and proximalmost outer spine on third segment of leg 1 very short. Distal outer spiniform process on second endopod segment of legs 1 and 2 simple, but in legs 3 and 4 minutely bifurcate. Right endopod of leg 2 in 1 female with second segment having 3 inner setae (Fig. 2j) instead of 2; left endopod normal. Right exopod of leg 3 in 1 female with third segment having 3 inner setae (Fig. 21) instead of 4; left exopod normal.

Leg 5 (Fig. 3b) 2-segmented. Proximal segment bearing 1 outer seta $52 \mu \mathrm{m}$ and produced as inner triangular smooth flap. Distal segment $62 \times 18 \mu \mathrm{m}$, its 4 setae from outer to inner $8,30,20$, and $17 \mu \mathrm{m}$. In 1 female right leg 5 having inner flap much more attenuated than usual (Fig. 3c), left leg normal.

Leg 6 probably represented by seta and spine on genital area (Fig. Id).

Color of living specimens unknown, but specimens in ethyl alcohol pale bluish gray.

Male. Body (Fig. 3d) resembling that of female in general form. Length 0.56 $\mathrm{mm}(0.54-0.58 \mathrm{~mm})$ and greatest width $0.14 \mathrm{~mm}(0.13-0.15 \mathrm{~mm})$, based on 10 specimens. Dorsoventral thickness $132 \mu \mathrm{m}$ at level of ventral protuberance, $160 \mu \mathrm{m}$ at level of oral cone. 


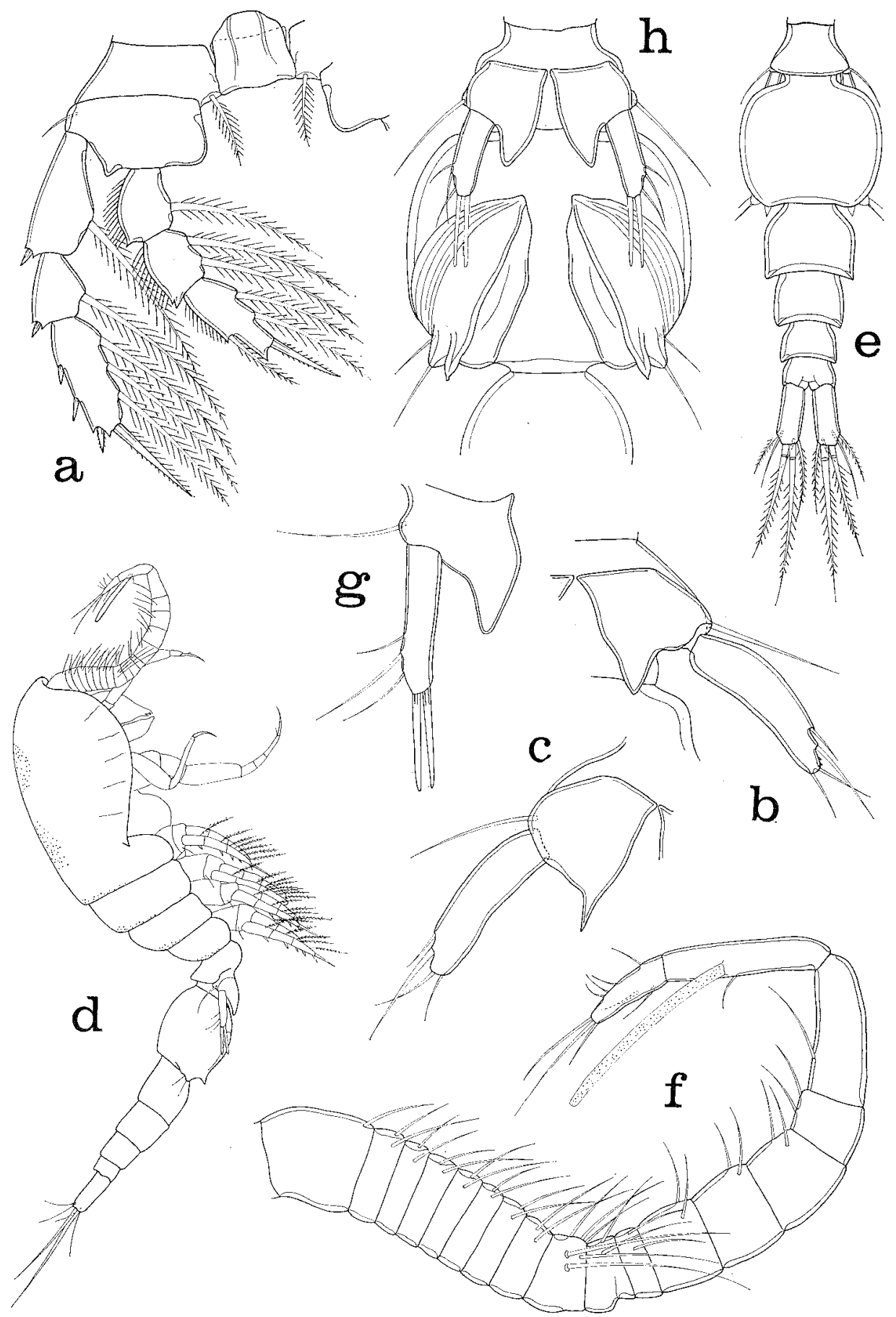

Fig. 3. Collocheres comanthiphilus, new species. Female. a, leg 4 and intercoxal plate, anterior (scale F) ; b, leg 5, ventral (F); c, right leg 5, abnormal, ventral (F). Male. d, lateral (E); e, urosome, dorsal (B); f, first antenna, anterior (D); g, leg 5 , ventral (D); h, leg 5 and leg 6 , ventral $(\mathrm{F})$. 
Segment bearing leg 5 (Fig. 3e) $36 \times 57 \mu \mathrm{m}$. Genital segment $91 \times 102 \mu \mathrm{m}$, with rounded lateral margins in dorsal view. Four postgenital segments from anterior to posterior $49 \times 65,39 \times 48,29 \times 37$, and $21 \times 36 \mu \mathrm{m}$.

Caudal ramus resembling that of female but smaller, $44 \times 18 \mu \mathrm{m}$, ratio $2.5: 1$.

Body surface as in female.

Rostral area like that of female. First antenna (Fig. 3f) 18-segmented, geniculate, with segment 17 bearing aesthete $60 \mu \mathrm{m}$ long. Segment 10 showing partial subdivision. Armature: 1, 2, 2, 2, 2, 2, 2, 2, 6, 2, 2, 2, 2, 2, 2, 1, 1 +aesthete, and 9. Second antenna as in female.

Oral cone, mandible, first maxilla, second maxilla, maxilliped, ventral postoral area, and legs 1-4 similar to those of female.

Leg 5 (Fig. 3g) resembling that of female but with 5 setae. Seta on first segment $30 \mu \mathrm{m}$. Second segment $36 \times 8 \mu \mathrm{m}$, with 3 slender outer setae 10,24 , and $14 \mu \mathrm{m}$, and 2 terminal broad hyaline setae approximately $25 \mu \mathrm{m}$.

Leg 6 (Fig. 3h) usual posteroventral flap on genital segment with 2 setae 25 $\mu \mathrm{m}$ and $24 \mu \mathrm{m}$, and spiniform process.

Body surface and color of living specimens as in female.

Etymology. The specific name comanthiphilus is a combination of the generic name of the host crinoid and philus, Greek meaning beloved, dear.

Remarks. The principal distinguishing characters of Collocheres comanthiphilus, based on the female, are: (1) the length to width ratio of the caudal ramus $3.15: 1$, (2) the short terminal claw on the second antenna, the ratio of its length to that of the four segments combined $1: 5.78$, (3) the very short mandibular palp, the ratio of its length to that of the blade $1: 4.87$, (4) the seta on the exopod of the first maxilla short, only 1.6 times longer than the segment, (5) the distal segment of leg 5 with the length to width ratio $3.44: 1$, and (6) the sides of the genital segment of the female not serrated.

The shorter caudal ramus distinguishes C. comanthiphilus from C. canui Giesbrecht, 1897, C. breei Stock, 1966, C. gracilipes Stock, 1966, and C. gracilicauda (Brady, 1880), in all of which the caudal ramus of the female has a ratio greater than $7: 1$ (see Stock, 1966a, key on p. 224). The presence of four setae instead of three on the distal segment of leg 5 of the female separates the new species from C. elegans A. Scott, 1896. Collocheres comanthiphilus differs from C. giesbrechti Thompson \& A. Scott, 1903, which has a long mandibular palp reaching to the end of the blade and two setae instead of one on the exopod of the first maxilla. The long bent seta on the exopod of the first maxilla distinguishes $C$. uncinatus Stock, 1966, from the new species.

\section{Collocheres titillator, new species}

(Figs 4-6)

Type material. 74우, 21 ðð, from 1 crinoid, Comaster gracilis (Hartlaub), in $10 \mathrm{~m}$, Poelau Parang, 
Ceram, Moluccas, $03^{\circ} 17^{\prime} 00^{\prime \prime} \mathrm{S}, 130^{\circ} 44^{\prime} 48^{\prime \prime} \mathrm{E}, 23$ May 1975. Holotype $q$, allotype, and 86 paratypes $\left(68+9\right.$, $\left.180^{\pi}\right)$ deposited in the National Museum of Natural History, Smithsonian Institution, Washington, D.C.

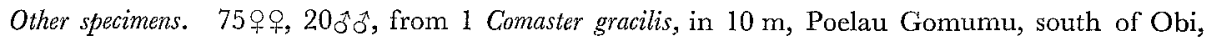
Moluccas, $01^{\circ} 50^{\prime} 00^{\prime \prime} \mathrm{S}, 127^{\circ} 30^{\prime} 45^{\prime \prime} \mathrm{E}, 30$ May 1975.

Female. Body (Fig. 4a) flexed (dorsal view not drawn because dorsal orientation resulted in distortion). Length $0.62 \mathrm{~mm}(0.58-0.65 \mathrm{~mm})$ and greatest width $0.21 \mathrm{~mm}(0.19-0.23 \mathrm{~mm})$, based on 10 specimens in lactic acid. Dorsoventral thickness at level of ventral protuberance in front of first pair of legs $185 \mu \mathrm{m}$. Ratio of length to width of prosome $1.57: 1$. Ratio of length of prosome to that of urosome $1.43: 1$.

Segment bearing leg 5 (Fig. 4b) $57 \times 73 \mu \mathrm{m}$. Genital segment $96 \mu \mathrm{m}$ long including posterolateral spiniform processes, $62 \mu \mathrm{m}$ wide at slightly swollen anterior third, and $57 \mu \mathrm{m}$ wide along posterior two-thirds (with parallel edges in dorsal view). Genital areas located laterally in anterior third (Fig. 4c), with each area bearing 2 minute setae. Three postgenital segments from anterior to posterior $39 \times 49,21 \times$ 42 , and $26 \times 42 \mu \mathrm{m}$.

Caudal ramus (Fig. $4 \mathrm{~d}$ ) elongate, $50 \times 19 \mu \mathrm{m}$, ratio $2.63: 1$. Outer lateral seta $44 \mu \mathrm{m}$, dorsal seta $38 \mu \mathrm{m}$, both smooth. Outermost terminal seta $50 \mu \mathrm{m}$, displaced subterminally, innermost terminal seta $66 \mu \mathrm{m}$, with swollen proximal part, and 2 median terminal setae $127 \mu \mathrm{m}$ (outer) and $170 \mu \mathrm{m}$ (inner), latter slightly swollen distal to "joint"; all 4 of these setae pinnate.

Body surface with few minute sensilla on dorsal surface of segment bearing leg 5 and of anal segment; dorsal surface of posterior third of genital segment and 3 postgenital segments with many minute refractile points (Fig. 4b).

Egg sac not seen.

Rostrum (Fig. 4e) prominent, beaklike. First antenna (Fig. 4f) 20-segmented, $244 \mu \mathrm{m}$ long, not including terminal setae. Armature: 1, 2, 2, 2, 2, 2, 2, 2, 6, 2, 2, $2,2,2,2,2,2,3+1$ aesthete, 2, and 9. All setae smooth. Aesthete $52 \mu \mathrm{m}$ long.

Second antenna (Fig. 4g) $122 \mu \mathrm{m}$ long, not including long slender terminal seta $78 \mu \mathrm{m}$. Small 1-segmented oval exopod with 3 setae. First segment of 2 -segmented endopod with proximal indentation. Few minute outer setules and very small inner spine on second segment of endopod.

Oral cone (Fig. 4a, e) prominent. Mandible (Fig. 4h) with very long indistinctly jointed palp $180 \mu \mathrm{m}$ long and with slender blade $66 \mu \mathrm{m}$ bearing several small teeth terminally (Fig. 4i). First maxilla (Fig. 5a) with outer lobe having 1 seta, inner lobe with 4 setae, all setae smooth. Second maxilla (Fig. 5b) with elongate basal segment; both segments of claw elongate and slender. Maxilliped (Fig. 5c) 5 -segmented. First segment short with 1 small distal inner seta. Second segment elongate, $86 \mu \mathrm{m}$, no seta visible. Third segment short with 1 small seta. Fourth segment unarmed. Fifth segment with 1 seta. Claw very long and slender, $81 \mu \mathrm{m}$.

Ventral area between maxillipeds and first pair of legs protruding as in Fig. 4a. Minute sclerite in front of intercoxal plate of leg 1. 


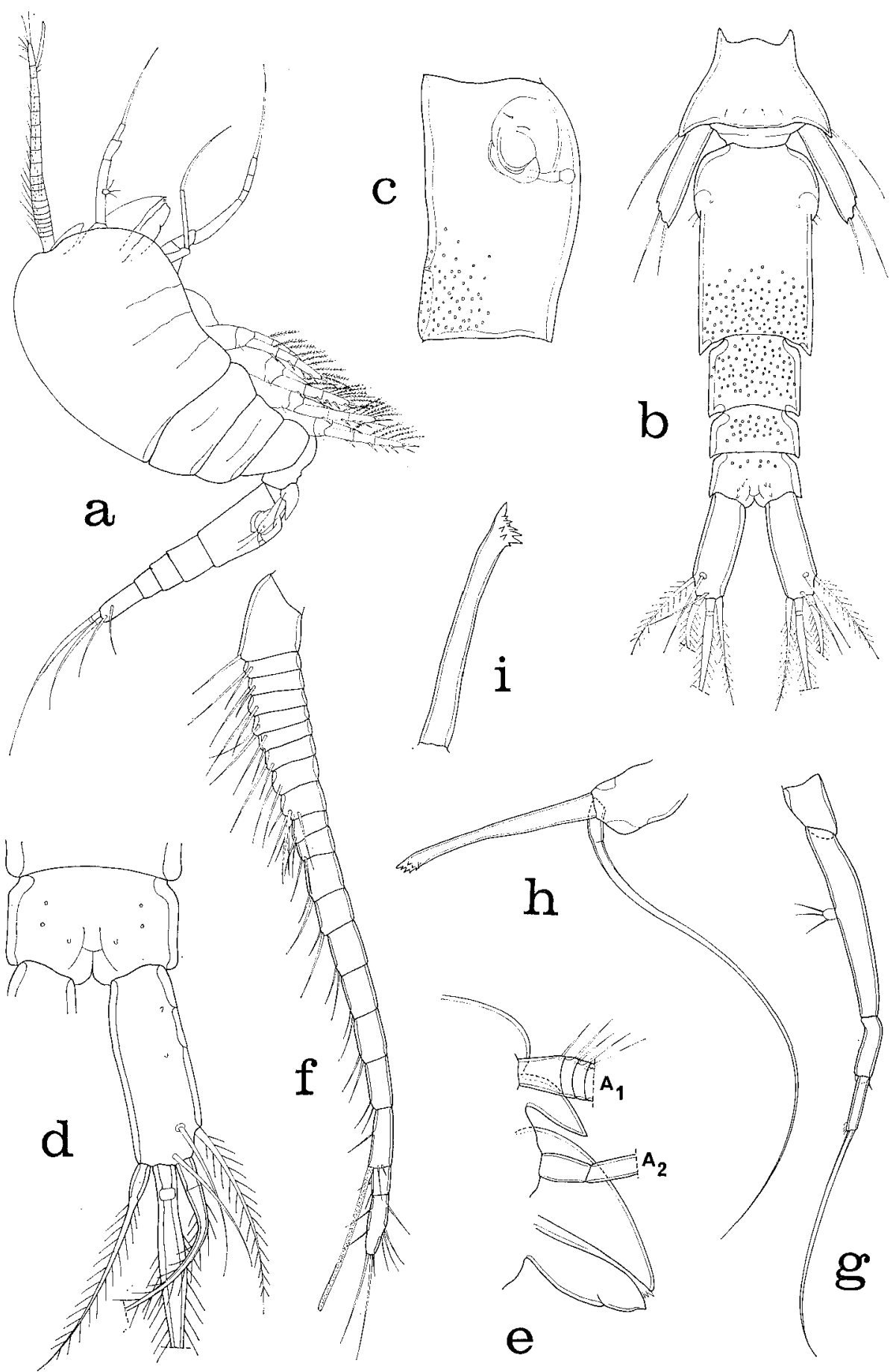

Fig. 4. Collocheres titillator, new species, female. a, lateral (sacle E); b, urosome, dorsal (C); c, genital segment, lateral $(F)$; d, anal segment and caudal ramus, dorsal (D); e, rostrum and oral cone, lateral $(\mathrm{C}) ; \mathrm{f}$, first antenna, ventral $(\mathrm{F}) ; \mathrm{g}$, second antenna, ventral $(\mathrm{F}) ; \mathrm{h}$, mandible, inner $(F)$; i, blade of mandible, outer (D). 


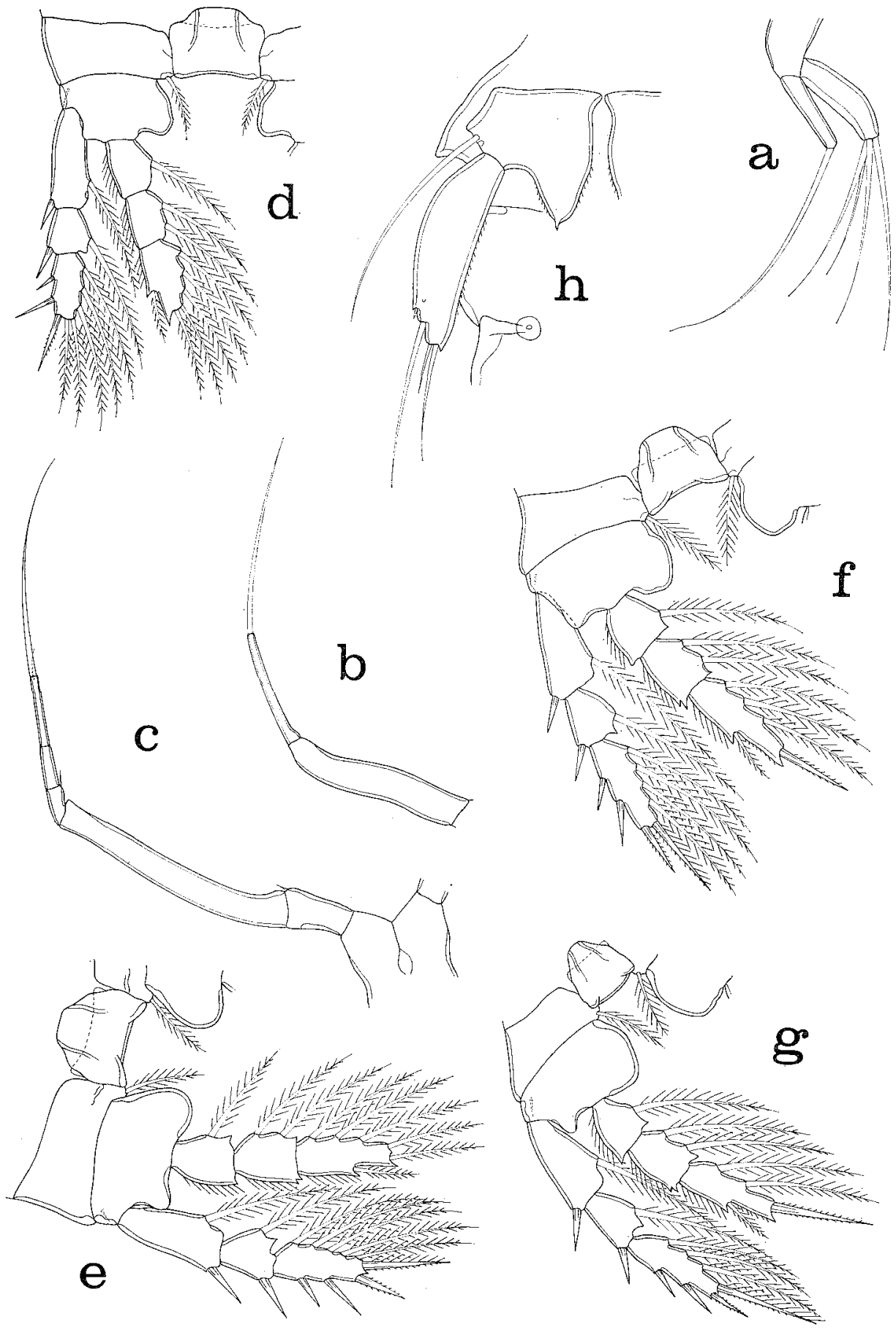

Fig. 5. Collocheres titillator, new species, female. a, first maxilla, anterior (scale D); $\mathrm{b}$, second maxilla, anterior $(\mathrm{F})$; c, maxilliped, posterior $(\mathrm{F})$; d, leg 1 and intercoxal plate, anterior (F); e, leg 1 and intercoxal plate, anterior (F); f, leg 3 and intercoxal plate, anterior (F); $\mathrm{g}$, leg 4 and intercoxal plate, anterior $(\mathrm{F}) ; \mathrm{h}$, leg 5 , ventral (D). 
Legs 1-4 (Figs 5d, e, f, g) biramous with 3-segmented rami. Spine and setal formula as follows:

\begin{tabular}{lllllllll}
$\mathrm{P}_{1}$ & coxa & $0-1$ & basis & $1-0$ & $\exp$ & $\mathrm{I}-1 ;$ & $\mathrm{I}-1 ;$ & $\mathrm{III}, 5$ \\
& & & & & $\operatorname{enp}$ & $0-1 ;$ & $0-2 ;$ & $1,2,3$ \\
$\mathrm{P}_{2}$ & coxa & $0-1$ & basis & $1-0$ & $\exp$ & $\mathrm{I}-1 ;$ & $\mathrm{I}-1 ;$ & $\mathrm{III}, \mathrm{I}, 5$ \\
& & & & & $\operatorname{enp}$ & $0-1 ;$ & $0-2 ;$ & $1,2,3$ \\
$\mathrm{P}_{3}$ & $\operatorname{coxa}$ & $0-1$ & basis & $1-0$ & $\exp$ & $\mathrm{I}-1 ;$ & $\mathrm{I}-1 ;$ & $\mathrm{II}, \mathrm{II}, 4$ \\
& & & & & $\operatorname{enp}$ & $0-1 ;$ & $0-2 ;$ & $1, \mathrm{I}, 3$ \\
$\mathrm{P}_{4}$ & $\operatorname{coxa}$ & $0-1$ & basis & \multirow{2}{*}{$1-0$} & $\exp$ & $\mathrm{I}-1 ;$ & $\mathrm{I}-1 ;$ & $\mathrm{II}, \mathrm{II}, 3$ \\
& & & & & $\operatorname{enp}$ & $0-1 ;$ & $0-2 ;$ & $1, \mathrm{I}, 2$
\end{tabular}

Basis of leg 1 without inner seta. Distal outer corner of second segment of endopod of leg 1 rounded, but in legs 2-4 with small bifurcate process. Third segment of exopod of legs 3 and 4 with II, II, rather than III, I as in C. comanthiphilus (cf. Figs 2k, 3a).

Leg 5 (Fig. 5h) 2-segmented. Proximal segment bearing smooth dorsal seta 53 $\mu \mathrm{m}$ and produced as inner triangular flap with minute nipple-like tip and having very small spinules along both sides. Distal segment elongate, slender, $50 \times 14 \mu \mathrm{m}$, bearing 4 distal smooth setae, from outer to inner 5,39, 10, and $28 \mu \mathrm{m}$, and having minute spinules along inner edge.

Leg 6 probably represented by 2 minute setae on genital area (Fig. 4c).

Color of living specimens opaque gray, prosome suffused with pale red, eye red, in some individuals gut bright red.

Male. Body (Fig. 6a) similar to that of female. Length $0.51 \mathrm{~mm}(0.42-0.56$ $\mathrm{mm}$ ) and greatest width $0.16 \mathrm{~mm}(0.13-0.18 \mathrm{~mm})$, based on 10 specimens. Dorsoventral thickness at level of ventral protuberance $138 \mu \mathrm{m}$.

Segment bearing leg 5 (Fig. 6b) $31 \times 66 \mu \mathrm{m}$. Genital segment in dorsal view rectangular, $60 \times 83 \mu \mathrm{m}$, wider than long. Four postgenital segments from anterior to posterior $43 \times 60,34 \times 49,19 \times 41$, and $17 \times 40 \mu \mathrm{m}$.

Caudal ramus resembling that of female but smaller, $39 \times 18 \mu \mathrm{m}$, ratio $2.17: 1$.

Body surface as in female.

Rostrum less prominent than in female, in lateral view hidden between bases of first antennae. First antenna (Fig. 6c) 18-segmented, geniculate, with aesthete on penultimate segment $83 \mu \mathrm{m}$. Segment 10 showing partial subdivision. Armature: $1,2,2,2,2,2,2,2,6,2,2,2,2,2,2,1,1+$ aesthete, and 9 .

Second antenna, oral cone, mandible, first maxilla, second maxilla, maxilliped, ventral protuberance, and legs $1-4$ as in female.

Leg 5 (Fig. 6d) similar to that of female, but free segment $41 \times 14 \mu \mathrm{m}$ with 2 short broad setae $11 \mu \mathrm{m}$ long added.

Leg 6 (Fig. 6d) usual posteroventral flap on genital segment having 2 small bifurcate processes and 1 small seta $22 \mu \mathrm{m}$.

Body surface and color of living specimens as in female. 


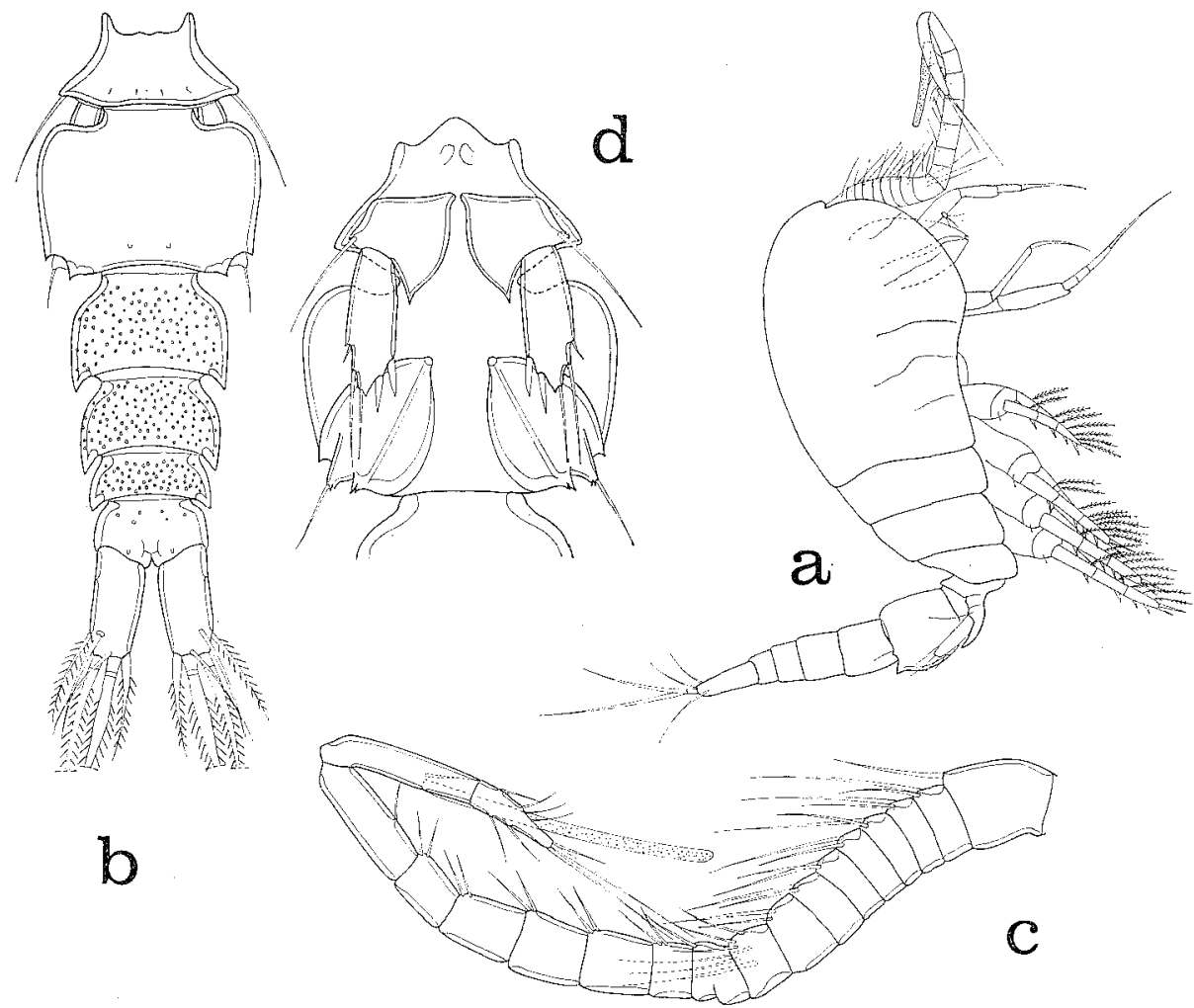

Fig. 6. Collocheres titillator, new species, male. a, lateral (scale E); b, urosome, dorsal (C); c, first antenna, posterior (F); d, leg 5 and leg 6 , ventral (F).

Etymology. The specific name titillator, Latin noun meaning one who tickles, is an allusion to the imagined use of the long terminal clawlike setae on the second antennae, the second maxillae, and the maxillipeds.

Remarks. Collocheres titillator may be readily distinguished from its congeners by the following features: (1) the long setiform claw on the second antenna, with the ratio of its length to that of the four segments combined being $1: 1.56$, (2) the very long mandibular palp, 2.7 times the length of the blade and reaching back to the first pair of legs, (3) the similarly very elongated terminal setae on the second maxilla and maxilliped, (4) the caudal ramus of the female having the ratio 2.63:1, and (5) the sides of the genital segment of the female not serrated.

\section{Collockeres serrulatus, new species}

(Fig. 7)

Type material. $3299,60^{\star}$ from 1 small crinoid, Comantheria rotula A.H. Clark, in $10 \mathrm{~m}$, south-

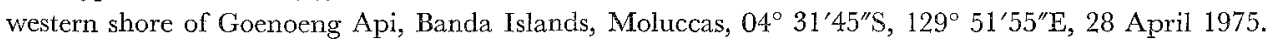
Holotype $q$, allotype, and 33 paratypes $\left(28+q, 4 \hat{\sigma} \sigma^{*}\right.$ ) deposited in the National Museun of Natural History, Smithsonian Institution, Washington, D.C. 
Female. Body form similar to that of Collocheres comanthiphilus. Length $0.85 \mathrm{~mm}$ $(0.80-0.88 \mathrm{~mm})$ and greatest width $0.30 \mathrm{~mm}(0.28-0.32 \mathrm{~mm})$, based on 10 specimens. Dorsoventral thickness at level of ventral protuberance in front of first pair of legs $0.20 \mathrm{~mm}$.

Segment bearing leg 5 (Fig. 7a) $65 \times 107 \mu \mathrm{m}$. Genital segment $143 \times 99 \mu \mathrm{m}$, including posterolateral spiniform processes, $135 \mu \mathrm{m}$ long without these processes. Entire segment barrel-shaped in dorsal view, with 5-7 small serrulations along margins of distal two-thirds, these serrulations appearing as fine ridges in lateral view (Fig. 7b). Genital areas located laterally on anterior third of segment. Each area with small seta and minute spine. Three postgenital segments from anterior to posterior $55 \times 60$ (including processes), $39 \times 49$, and $36 \times 44 \mu \mathrm{m}$.

Caudal ramus (Fig. 7c) elongate, $61 \times 19 \mu \mathrm{m}$, ratio 3.21:1. Six setae arranged as in C. comanthiphilus. Outer lateral seta $40 \mu \mathrm{m}$ and dorsal seta $50 \mu \mathrm{m}$, both smooth. Outermost terminal seta $50 \mu \mathrm{m}$ and displaced subterminally, innermost terminal seta $71 \mu \mathrm{m}$, and 2 long terminal median setae $122 \mu \mathrm{m}$ (outer) and $198 \mu \mathrm{m}$ (inner); all 4 terminal setae with lateral hairs.

Ventral protuberance in front of first pair of legs as in $C$. comanthiphilus.

Body surface lacking sensilla except for pair on dorsal surface of anal segment.

Egg sac unknown.

Rostral area, first antenna (368 $\mu \mathrm{m}$ long with aesthete $83 \mu \mathrm{m}$ ), second antenna, oral cone, mandible (blade $83 \mu \mathrm{m}$ ), first maxilla, second maxilla, maxilliped, leg 1 , and leg 2 resembling those of $C$. comanthiphilus. Leg 3 (Fig. 7d) with inner margin of basis not as expanded as in $C$. comanthiphilus and exopod having formula $1-1$; I-1; III,I,4. Leg 4 (Fig. 7e) with inner margin of basis less expanded than in $C$. comanthiphilus.

Leg 5 (Fig. 7f) with first segment bearing dorsal outer seta $52 \mu \mathrm{m}$ and having bluntly rounded triangular smooth expansion. Second segment elongate, $62 \times 18$ $\mu \mathrm{m}$, its 4 setae from outer to inner $15,26,34$, and $10 \mu \mathrm{m}$.

Leg 6 as in C. comanthiphilus.

Color of living specimens pale amber, eye red.

Male. Body as in C. comanthiphilus. Length $0.59 \mathrm{~mm}(0.58-0.59 \mathrm{~mm})$ and greatest width $0.18 \mathrm{~mm}(0.17-0.19 \mathrm{~mm})$, based on 3 specimens. Dorsoventral thickness $0.11 \mathrm{~mm}$ at level of ventral protuberance.

Segment bearing leg 5 (Fig. $7 \mathrm{~g}$ ) $34 \times 60 \mu \mathrm{m}$. Genital segment wider than long, $78 \times 99 \mu \mathrm{m}$ (including posterolateral spiniform processes) with gently rounded lateral margins in dorsal view. Four postgenital segments from anterior to posterior $55 \times$ $60,44 \times 47,26 \times 36$, and $21 \times 34 \mu \mathrm{m}$, first 2 of these segments with small posterolateral spiniform processes.

Caudal ramus $31 \times 17 \mu \mathrm{m}$, ratio 1.82:1. Otherwise as in female.

All appendages on cephalosome (aesthete on first antenna $81 \mu \mathrm{m}$ long), oral cone, and legs 1 and 2 as in C. comanthiphilus. Legs 3 and 4 as in female.

Leg 5 (Fig. 7h, i) resembling that of female, but with 5 setae. Seta on first 


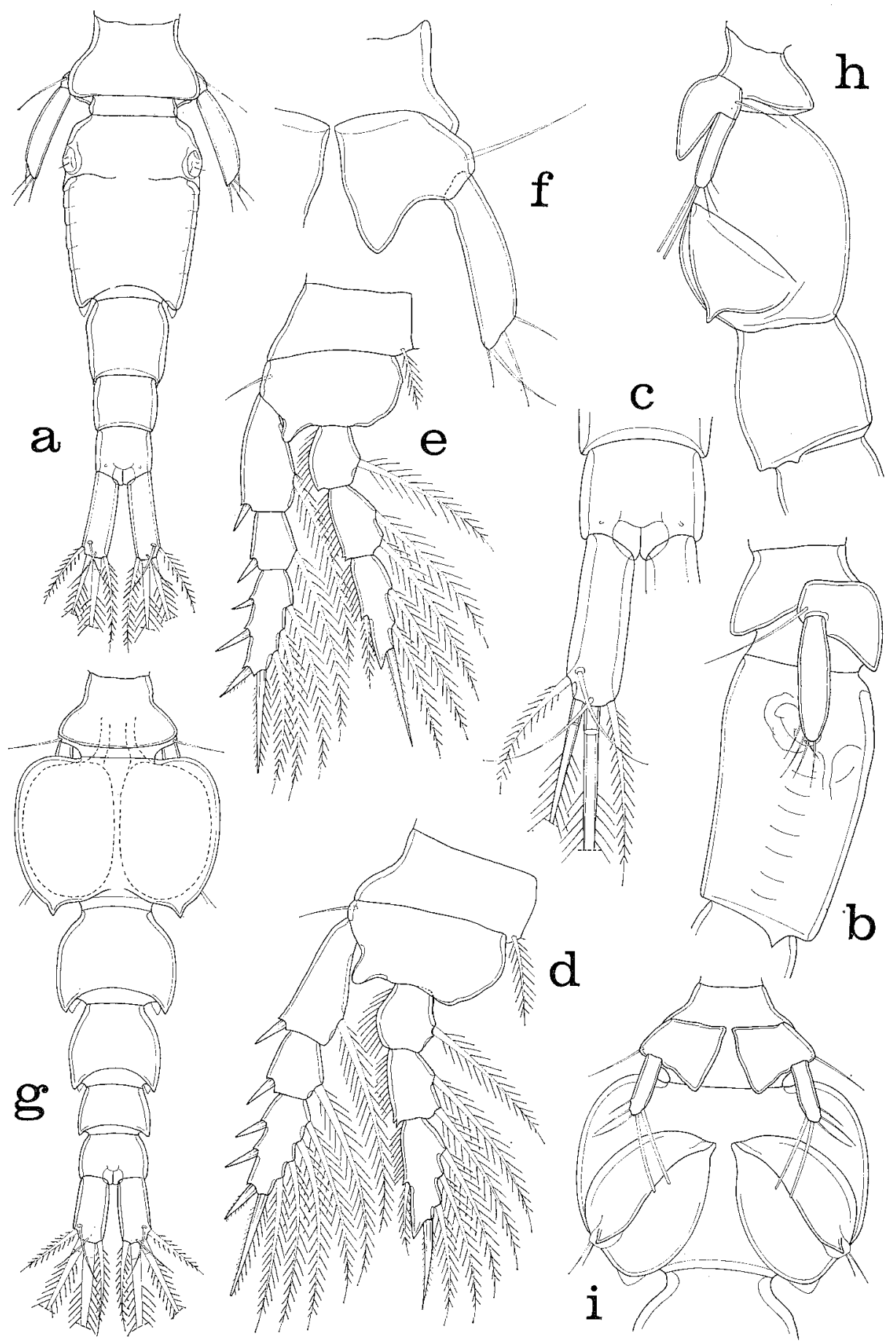

Fig. 7. Collocheres serrulatus, new species. Female. a, urosome (scale B); b, segment bearing leg 5 and genital segment, lateral $(\mathrm{C})$; c, anal segment and caudal ramus, dorsal $(\mathbf{F})$; d, leg 3 , anterior $(\mathrm{F})$; $\mathrm{e}, \operatorname{leg} 4$, anterior $(\mathrm{F}) ; \mathrm{f}, \operatorname{leg} 6$, ventral $(\mathrm{F})$. Male. $g$, urosome, dorsal $(\mathrm{C})$; $h$, segment bearing leg 5 , genital segment, and first postgenital segment, lateral $(F)$; $i$ leg 5 and $\operatorname{leg} 6$, ventral $(F)$. 
segment $28 \mu \mathrm{m}$. Second segment $29 \times 8 \mu \mathrm{m}$, terminally with 3 slender outer setae 10,18 , and $18 \mu \mathrm{m}$, and 2 long inner stouter hyaline setae $33 \mu \mathrm{m}$.

Leg 6 (Fig. 7i) with 2 small delicate setae and spiniform process.

Color as in female.

Etymology. The specific name serrulatus, Latin meaning having little sawlike teeth, alludes to the serrulate margins of the genital segment of the female.

Remarks. Collocheres serrulatus differs from three congeners that have serrulations along the sides of the genital segment of the female as follows: from Collocheres inaequalis Ho, 1982, in which the first segment of the first antenna of the female bears a row of hairs, the genital areas are located less anteriorly than in the new species, the caudal ramus has a row of long inner setules, and the two inner elements on the free segment of leg 5 each have a sharp triangular subterminal hyaline plate; from Collocheres uncinatus Stock, 1966, in which the first segment of the first antenna of the female bears a row of hairs, the inner margin of the caudal ramus is ciliated, and the terminal element on the outer lobe of the first maxilla is very long and rectangularly bent; and from Collocheres marginatus, described below, in which the ratio of the female caudal ramus is only $2: 1$, and the seta on the outer lobe of the first maxilla is very long and has a broad hyaline lamella.

\section{Collocheres inflatiset $a_{\text {, new species }}$}

(Figs 8-10)

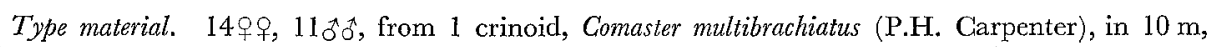
Poelau Gomumu, south of Obi, Moluccas, $01^{\circ} 50^{\prime} 00^{\prime \prime} \mathrm{S}, 127^{\circ} 30^{\prime} 54^{\prime \prime} \mathrm{E}$, 30 May 1975 . Holotype $q$, allotype, and 17 paratypes $(9 \circ 9,8 \% \pi)$ deposited in the National Museum of Natural History, Smithsonian Institution, Washington, D.G.

Female. Body (Fig. 8a) flexed at junction of prosome and urosome in specimens preserved in $70 \%$ alcohol. Length $0.63 \mathrm{~mm}(0.62-0.65 \mathrm{~mm})$ and greatest width $0.22 \mathrm{~mm}(0.22-0.23 \mathrm{~mm})$, based in 10 specimens. Dorsoventral thickness at level of ventral protuberance in front of first pair of legs $0.19 \mathrm{~mm}$.

Segment bearing leg 5 (Fig. 8b) $56 \times 83 \mu \mathrm{m}$. Genital segment $114 \times 70 \mu \mathrm{m}$, much longer than wide, subrectangular. Genital areas situated dorsolaterally between first and second thirds of segment. Each area bearing very small spine and minute seta. Ventral surface of segment (Fig. 8c) with pair of refractile areas at level of genital openings. Three postgenital segments from anterior to posterior $42 \times 52,23 \times 43$, and $26 \times 45 \mu \mathrm{m}$.

Caudal ramus (Fig. 8d) elongate, $47 \times 20 \mu \mathrm{m}$, ratio 2.35:1. Outer lateral seta, displaced dorsally, $48 \mu \mathrm{m}$ and dorsal seta $12 \mu \mathrm{m}$, both smooth. Outermost terminal seta $56 \mu \mathrm{m}$, displaced subterminally and with lateral hairs. Innermost terminal seta $84 \mu \mathrm{m}$, swollen proximally (width $6.5 \mu \mathrm{m}$ ) and bearing long lateral setules. Two median terminal setae $91 \mu \mathrm{m}$ (outer) and $130 \mu \mathrm{m}$ (inner), both with lateral setules. Median edge of ramus with row of long setules. 


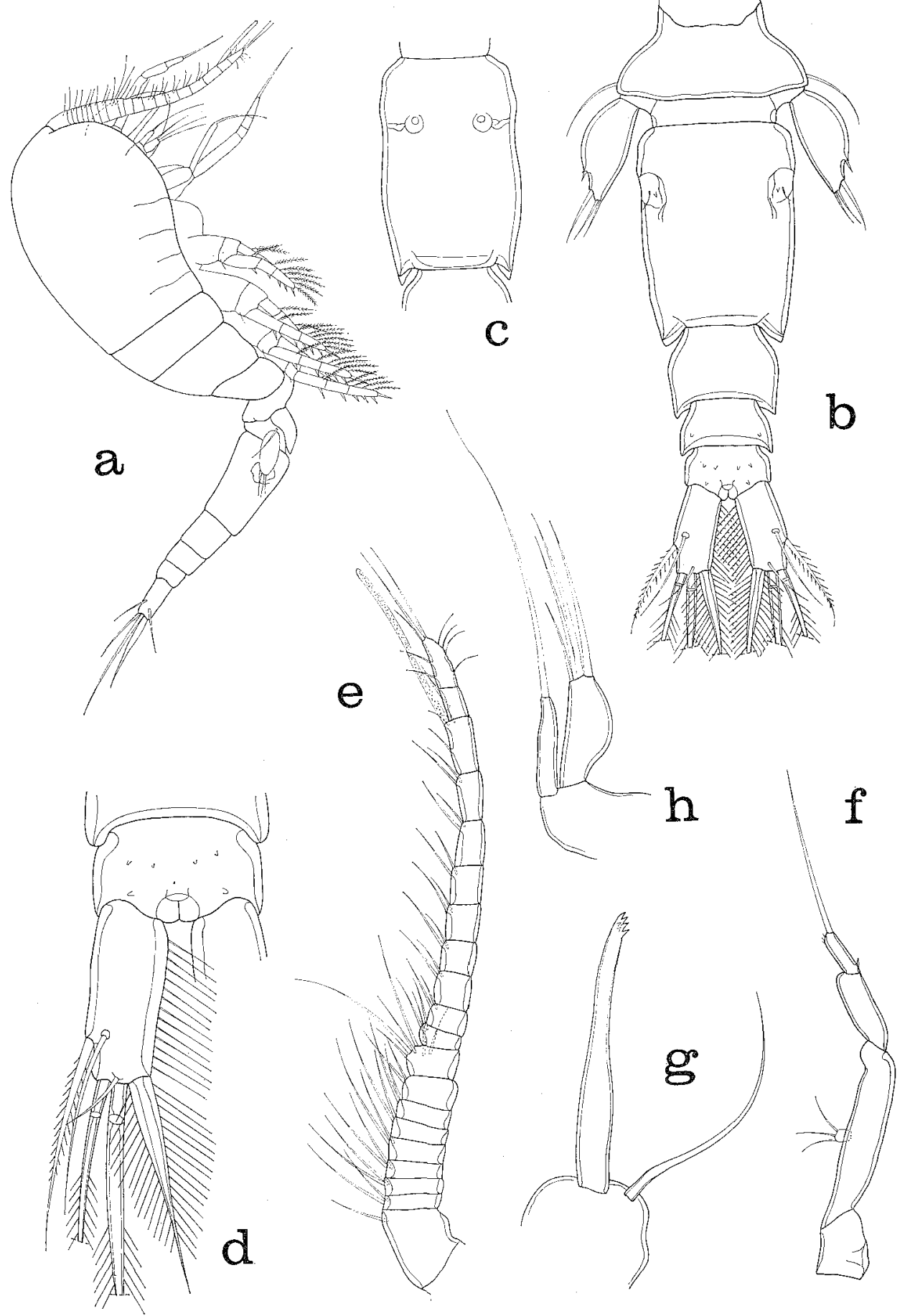

Fig. 8. Collocheres inflatiseta, new species, female. a, lateral (scale E); b, urosome, dorsal (C); c, genital segment, ventral $(\mathrm{C})$; d, anal segment and caudal ramus, dorsal $(\mathrm{C})$; e, first antenna, dorsal $(\mathbf{F})$; $f$, second antenna, anteroventral $(\mathbf{F})$; g, mandible, antero-outer (D); h, first maxilla, anterior (D). 


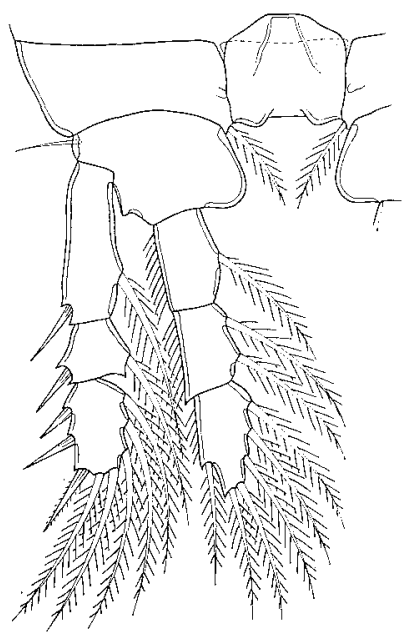

C

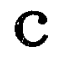

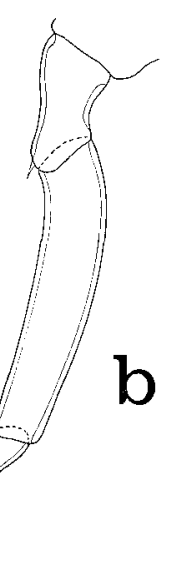
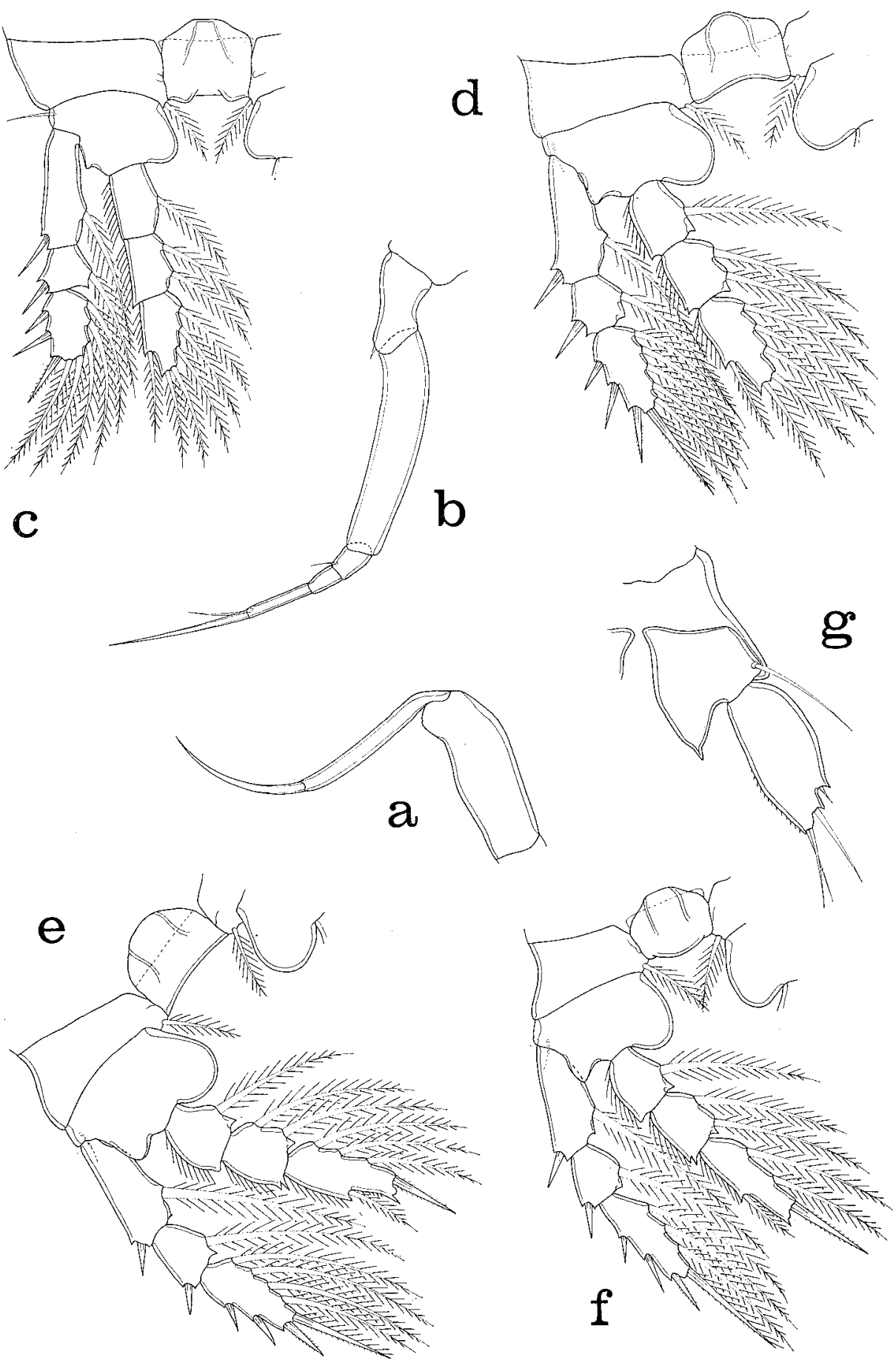

Fig. 9. Collocheres inflatiseta, new species, female. a, second maxilla, anterior (scale F); b, maxilliped, anterior $(\mathrm{F})$; c, leg 1 and intercoxal plate, anterior $(\mathrm{F})$; d, leg 2 and intercoxal plate, anterior $(\mathbf{F})$; e, leg 3 and intercoxal plate, anterior $(F) ; f$, leg 4 and intercoxal plate, anterior $(\mathrm{F})$; g, leg 5, ventral $(\mathrm{F})$. 
Body surface without ornamentation except few sensilla on dorsal surface of second and third postgenital segments (Fig. 8b).

Egg sac unknown.

Rostral area undeveloped. First antenna (Fig. 8e) 20-segmented, $237 \mu \mathrm{m}$ long, and armed as in Collocheres comanthiphilus; aesthete $64 \mu \mathrm{m}$. Second antenna (Fig. 8f) $174 \mu \mathrm{m}$ long including straight terminal seta $47 \mu \mathrm{m}$.

Oral cone (Fig. 8a) as in C. comanthiphilus. Mandible (Fig. 8g) with long seta (palp) on basal part; slender blade $74 \mu \mathrm{m}$ long with few terminal teeth. First maxilla (Fig. 8h) with seta on outer lobe longer than setae on inner lobe. Second maxilla (Fig. 9a) with claw having slender first segment and recurved second segment. Maxilliped (Fig. 9b) resembling that of C. comanthiphilus but seta on second segment not seen; claw $65 \mu \mathrm{m}$, slender.

Ventral surface of body in front of first pair of legs with median protuberance (Fig. 8a).

Legs 1-4 (Fig. 9c, d, e, f) resembling those of $C$. comanthiphilus, with similar armature, except for longer spines on exopods than in that species.

Leg 5 (Fig. 9g) 2-segmented. Proximal segment bearing outer seta $41 \mu \mathrm{m}$ and produced as subtriangular inner lobe with mucronate tip. Distal segment $52 \times 26$ $\mu \mathrm{m}$, ratio $2: 1$, relatively broader than in other species, its 4 setae from outer to inner $7,31,27$, and $27 \mu \mathrm{m}$. (Setae in some specimens very hyaline and difficult to see.) Inner margin of distal segment with row of small spinules.

Leg 6 probably represented by small spine and seta on genital area (Fig. 8b).

Color of living specimens reddish wine-colored, eye red.

Male. Body (Fig. 10a) flexed as in female. Length $0.54 \mathrm{~mm}(0.52-0.56 \mathrm{~mm})$ and greatest width $0.17 \mathrm{~mm}(0.17-0.18 \mathrm{~mm})$, based on 5 specimens. Dorsoventral thickness at level of ventral protuberance in front of first pair of legs $0.14 \mathrm{~mm}$.

Segment bearing leg 5 (Fig. 10b) $35 \times 64 \mu \mathrm{m}$. Genital segment $61 \times 83 \mu \mathrm{m}$, wider than long. Four postgenital segments from anterior to posterior $49 \times 75,34 \times$ $62,23 \times 45$, and $21 \times 40 \mu \mathrm{m}$.

Caudal ramus similar to that of female but smaller, $39 \times 18 \mu \mathrm{m}$, ratio $2.17: 1$.

Rostral area undeveloped as in female. First antenna (Fig. 10c) 18-segmented, geniculate, armed as in male of $G$. comanthiphilus; aesthete $68 \mu \mathrm{m}$. Second antenna as in female.

Oral cone, mandible, first maxilla, second maxilla, maxilliped, postoral area, and legs $1-4$ as in female.

Leg 5 (Fig. 10d) resembling that of female but with 5 setae on second segment. Seta on first segment $32 \mu \mathrm{m}$. Second segment $39 \times 16 \mu \mathrm{m}$, with 3 slender outer setae 7,22 , and $24 \mu \mathrm{m}$, and 2 inner stout hyaline bluntly tipped setae $12 \mu \mathrm{m}$.

Leg 6 (Fig. 10d) usual posteroventral flap on genital segment with small spiniform outer process, lobe bearing 2 short setae, and inner bifurcate spiniform process.

Body surface as in female.

Spermatophore unknown. 


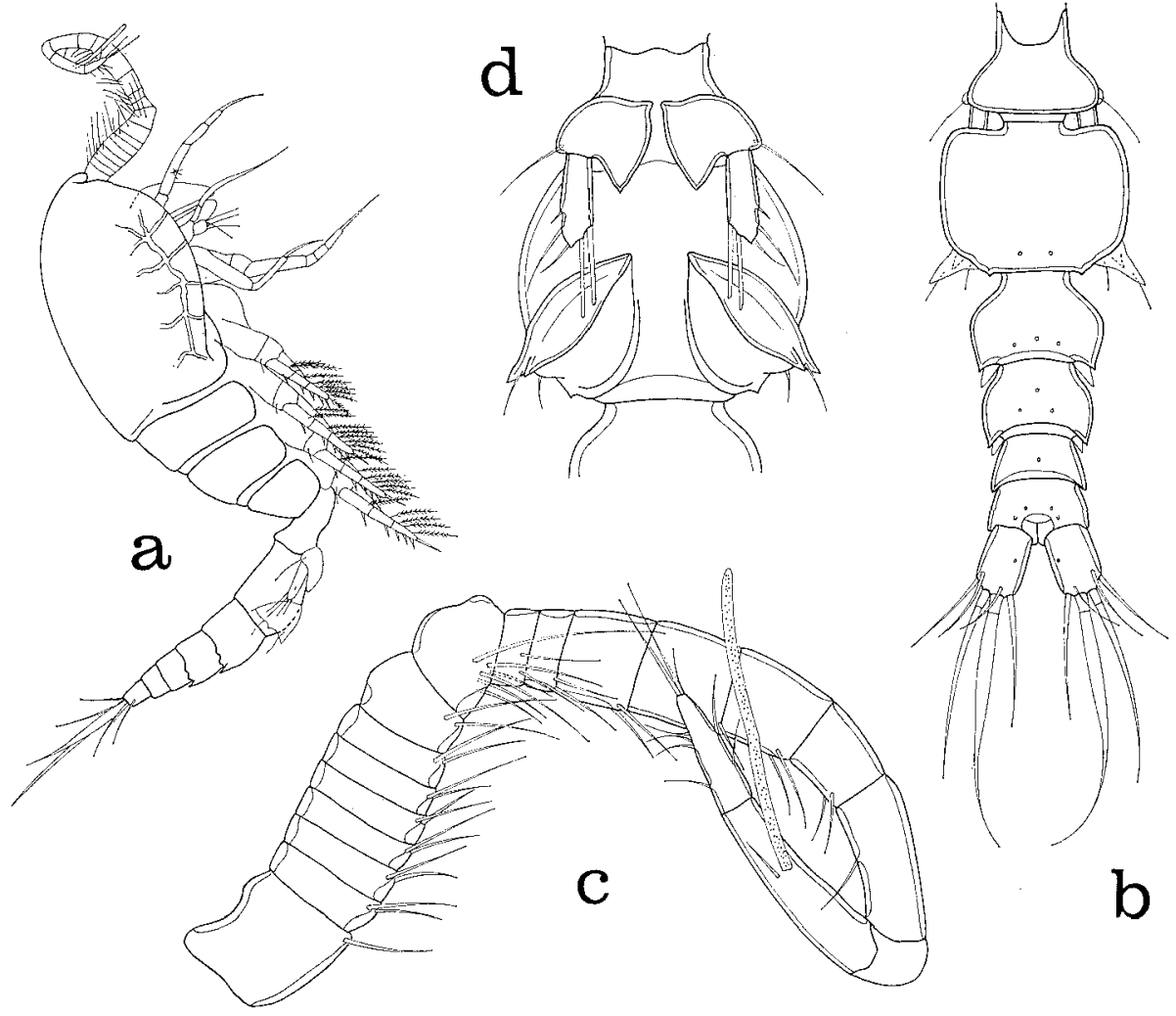

Fig. 10. Collocheres inflatiseta, new species, male. a, lateral (scale E); b, urosome, dorsal (G); c, first antenna, ventral (D); d, leg 5 and leg 6, ventral (F).

Etymology. The specific name inflatiseta, Latin inflatus meaning swollen and seta, refers to the swollen innermost terminal seta on the caudal ramus.

Remarks. Collocheres inflatiseta may be distinguished from its congeners by the proximally inflated innermost terminal seta on the caudal ramus. In the female the ratio of the caudal ramus is 2.35:1 and the distal segment of leg 5 is unusually short and broad, ratio 2:1.

\section{Collocheres parvus, new species}

(Figs 11, 12)

Type material. 33 우, 1\%, from 1 crinoid, Comaster multibrachiatus (P.H. Carpenter), in $10 \mathrm{~m}$, Poelau Gomumu, south of Obi, Moluccas, $01^{\circ} 50^{\prime} 00^{\prime \prime} \mathrm{S}, 127^{\circ} 30^{\prime} 45^{\prime \prime} \mathrm{E}, 30$ May 1975 . Holotype \%, allotype, and 28 paratypes deposited in the National Museum of Natural History, Smithsonian Institution, Washington, D.C.

Female. Body (Fig. 1la, b) with prosome relatively wider than in most members of genus. Length $0.45 \mathrm{~mm}(0.43-0.47 \mathrm{~mm})$ and greatest width $0.20 \mathrm{~mm}(0.19-0.21$ $\mathrm{mm})$, based on 10 specimens. Dorsoventral thickness at level of ventral protuberance 


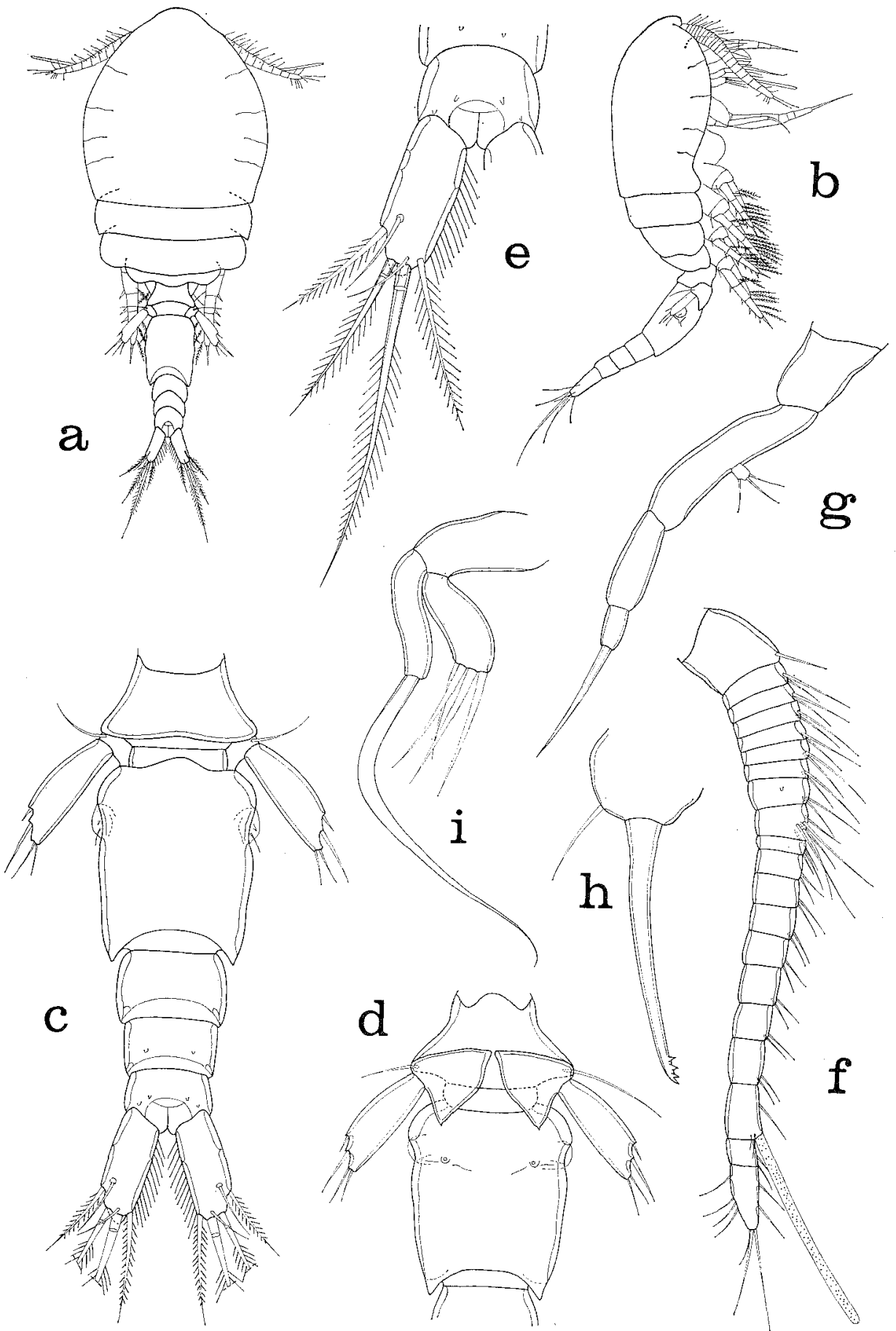

Fig. 11. Collocheres parvus, new species, female. a, dorsal (scale E); b, lateral (E); c, urosome, dorsal (F); d, leg 5 and genital segment, ventral (F); e, anal segment and caudal ramus, dorsal (D); f, first antenna, ventral (D); $g$, second antenna, ventral (D); $h$, mandible, posterior (D); i, first maxilla, posterior (D). 
in front of first pair of legs $112 \mu \mathrm{m}$. Ratio of length to width of prosome 1.64:1. Ratio of length of prosome to that of urosome 1.62:1.

Segment bearing leg 5 (Fig. 11c) $36 \times 55 \mu \mathrm{m}$. Genital segment longer than wide, subrectangular, $70 \mu \mathrm{m}$ long, $58 \mu \mathrm{m}$ wide at level of genital areas, $52 \mu \mathrm{m}$ wide in posterior fourth. Ventral surface of genital segment (Fig. 11d) with pair of small sclerotized areas. Genital areas situated laterally in anterior half of segment. Each area bearing minute spine and seta. Three postgenital segments from anterior to posterior $27 \times 38,21 \times 31$, and $21 \times 31 \mu \mathrm{m}$.

Caudal ramus (Fig. 1 le) elongate, $42 \times 15 \mu \mathrm{m}$, ratio 2.8:1. Outer lateral seta $24 \mu \mathrm{m}$ and displaced dorsally, dorsal seta $15 \mu \mathrm{m}$, both smooth. Outermost terminal seta $31 \mu \mathrm{m}$ and located subterminally, innermost terminal seta $44 \mu \mathrm{m}$, and 2 median terminal setae $55 \mu \mathrm{m}$ (outer) and $86 \mu \mathrm{m}$ (inner); all 4 terminal setae with lateral hairs. Ramus with row of long hairs along inner edge and having small terminal ventral flange.

Ventral area between maxillipeds and first pair of legs with median protuberance (Fig. 11b) as in other species.

Body surface smooth except for few sensilla on dorsal surface of last 2 postgenital segments (Fig. 11c).

Egg sac not seen.

Rostral area undeveloped. First antenna (Fig. 11f) 20-segmented, $234 \mu \mathrm{m}$ long, with armature as in $C$. comanthiphilus and other congeners. Aesthete on antepenultimate segment $48 \mu \mathrm{m}$. Terminal segment relatively shorter than in other species. Second antenna (Fig. $11 \mathrm{~g}$ ) $101 \mu \mathrm{m}$ long, not including terminal seta 26 $\mu \mathrm{m}$. Without fine ornamentation except for minute spine on second segment of endopod.

Oral cone with general shape as in $C$. comanthiphilus and other congeners.

Mandible (Fig. 11h) with seta (palp) on basal part, blade slender, $68 \mu \mathrm{m}$, with few terminal teeth. First maxilla (Fig. 11i) with long slightly swollen seta on outer lobe. Second maxilla (Fig. 12a) with second segment of claw shorter than first segment and having few terminal filaments. Body surface near insertion of second maxilla with small hyaline process (seta ?). Maxilliped (Fig. 12b) resembling that in other species, but only slight indication of seta on second segment. Claw 32 $\mu \mathrm{m}$.

Legs 1-4 (Fig. 12c, d, e, f) segmented and armed as in C. comanthiphilus with only minor differences in form.

Leg 5 (Fig. 11d) 2-segmented. Proximal segment bearing dorsal seta $34 \mu \mathrm{m}$ and expanded as triangular inner lobe with minute pointed tip. Distal segment $36 \times 14 \mu \mathrm{m}$, its 4 setae from outer to inner $5,17,10$, and $10 \mu \mathrm{m}$.

Leg 6 probably represented by small seta and spine on genital area (Fig. 11c).

Color of living specimens reddish wine-colored, eye red.

Male. Body (Fig. 12g) with general form similar to that of female. Length $0.34 \mathrm{~mm}$ and greatest width $0.15 \mathrm{~mm}$. Dorsoventral thickness at level of ventral 


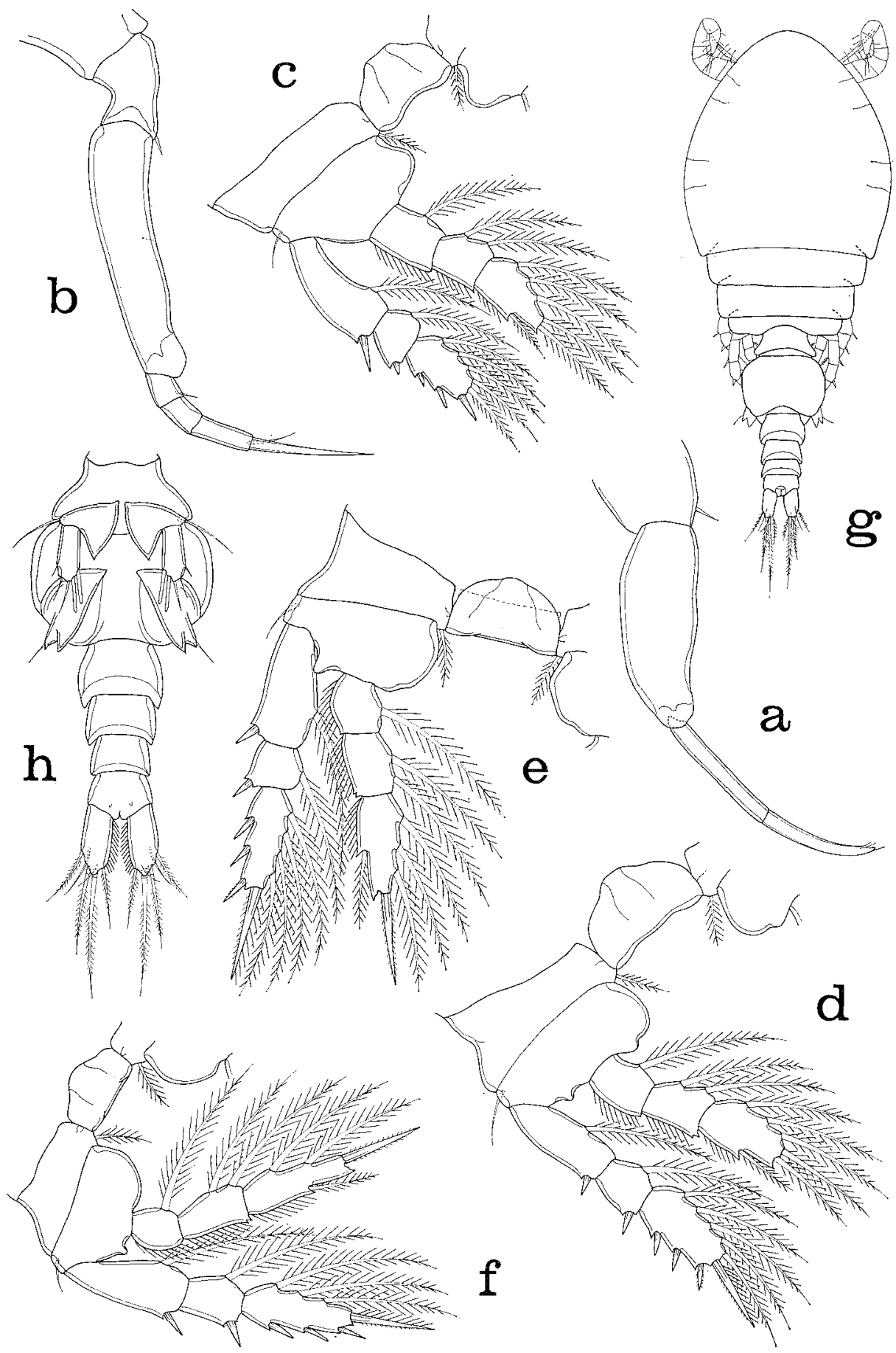

Fig. 12. Collocheres parous, new species. Female. a, second maxilla, posterior (D); b, maxilliped, posterior (D); c, leg 1 and intercoxal plate, anterior (D); d, leg 2 and intercoxal plate, anterior (D); e, leg 3 and intercoxal plate, anterior (D); f, leg 4 and intercoxal plate, anterior (D). Male. $\mathrm{g}$, dorsal (B); $h$, urosome, ventral (F). 
protuberance $79 \mu \mathrm{m}$. Ratio of length to width of prosome 1.5:1. Ratio of length of prosome to that of urosome $1.68: 1$.

Segment bearing leg 5 (Fig. 12h) $21 \times 40 \mu \mathrm{m}$. Genital segment wider than long, $46 \times 62 \mu \mathrm{m}$, with rounded lateral margins in dorsal view. Four postgenital segments from anterior to posterior $23 \times 31,18 \times 29,16 \times 26$, and $17 \times 26 \mu \mathrm{m}$.

Caudal ramus (Fig. 12h) $26 \times 12 \mu \mathrm{m}$, ratio 2.17:1.

Body surface as in female.

Rostral area undeveloped as in female. First antenna (geniculate) resembling that in other species. Second antenna, oral cone, mandible, first maxilla, second maxilla, maxilliped, and legs 1-4 as in female.

Leg 5 (Fig. 12h) similar to that of female but second segment, $21 \times 8 \mu \mathrm{m}$, with 5 setae, inner 2 setae broad and hyaline.

Leg 6 (Fig. 12h) with 2 spiniform processes and 1 small seta.

Spermatophore not seen.

Color of living specimens as in female.

Etymology. The specific name parvus, Latin meaning small, alludes to the relatively small body size.

Remarks. Collocheres parous is distinctly smaller than other species in the genus, the length of the female being $0.45 \mathrm{~mm}(0.43-0.57 \mathrm{~mm})$, whereas congeners range from $0.6 \mathrm{~mm}$ and longer. The caudal ramus of the female is relatively short, with a ratio of 2.8:1. The terminal seta on the second antenna is about one-fourth as long as the four segments combined, ratio 1:3.88. The mandibular palp is short, its length in relation to that of the blade as $1: 2.35$.

\section{Collocheres thysanotus, new species}

(Figs. 13-15)

Type material. 202우, 5600, from 1 crinoid, Comanthina variabilis (Bell), in 9-10 m, on reef north of East Point, Darwin, Northern Territory, Australia, $12^{\circ} 24^{\prime} 02^{\prime \prime} \mathrm{S}, 130^{\circ} 49^{\prime} 00^{\prime \prime} \mathrm{E}, 4$ March 1986, C. Johnson collector. Holotype $q$, allotype, and 124 paratypes $(98 q q, 26 \hat{\jmath})$ deposited in the Northern Territory Museum, Darwin, Australia; 126 paratypes (99우, 27 $\hat{\delta}$ ) in the National Museum of Natural History, Smithsonian Institution, Washington, D.C.

Other specimens. From Comanthina variabilis: 18 q , $3 \hat{\delta} \delta^{\star}$, from 1 host, in $9-10 \mathrm{~m}$, reef north of East Point, Darwin, Northern Territory, Australia, 4 March 1986, G. Johnson collector; 31 우, $7 \delta^{\star}$,

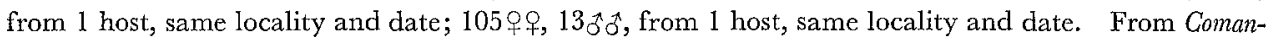

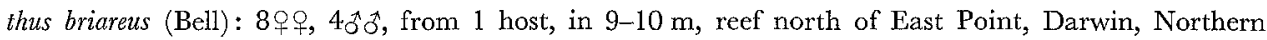
Territory, Australia, 4 March 1986, G. Johnson collector; 20 $q, 21$ ơ 0 , from 1 host, same locality and date.

Female. Body (Fig. 13a) strongly flexed in preserved specimens. Length 0.66 $\mathrm{mm}(0.65-0.68 \mathrm{~mm})$ and greatest width $0.18 \mathrm{~mm}(0.18-0.20 \mathrm{~mm})$, based on 10 specimens. Dorsoventral thickness at level of ventral protuberance in front of first pair of legs $187 \mu \mathrm{m}$. Segmentation of prosome well developed, with rounded epimeral areas. Ratio of length to width of prosome $2.24: 1$. Ratio of length of prosome to 


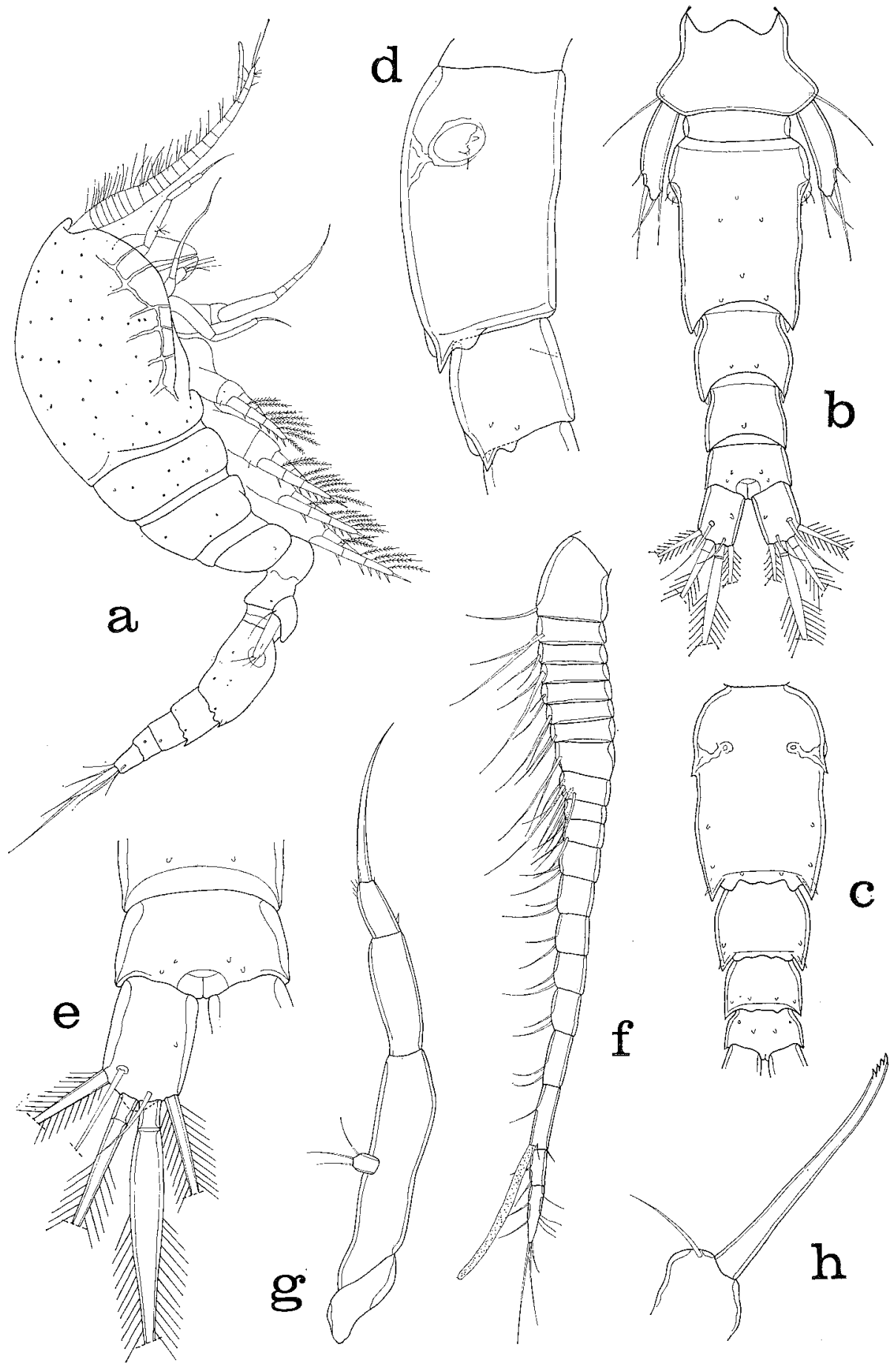

Fig. 13. Collocheres thysanotus, new species, female. a, lateral (scale E); b, urosome, dorsal (C); c, genital and postgenital segments, ventral (C); d, genital and first postgenital segment, lateral (F); e, anal segment and caudal ramus, dorsal (D); f, first antenna, ventral (F); g, second antenna, ventro-outer $(D) ; h$, mandible, posterior (D). 
that of urosome 1.61:1.

Segment bearing leg 5 (Fig. 13b) $55 \times 73 \mu \mathrm{m}$. Genital segment subrectangular, longer than wide, $94 \mu \mathrm{m}$ long, $70 \mu \mathrm{m}$ wide in anterior fourth, $60 \mu \mathrm{m}$ wide in posterior fourth. Minute spiniform process laterally posterior to both genital areas. Ventral surface of segment with pair of small round sclerotizations at level of genital openings (Fig. 13c). Segment with posterolateral corners having 2 spiniform processes and with posterior ventral margin bearing hyaline lobed fringe. Genital areas located laterally on slightly expanded anterior fourth (Fig. 13d). Each area with minute spine and seta. Three postgenital segments from anterior to posterior $44 \times 49,31 \times$ 39 , and $24 \times 40 \mu \mathrm{m}$. First postgenital segment with spiniform processes and hyaline lobed fringe as on genital segment, but second and third postgenital segments without processes or fringe.

Caudal ramus (Fig. 13e) short, $34 \times 20 \mu \mathrm{m}$, ratio 1.7:1. Outer lateral seta 55 $\mu \mathrm{m}$ and displaced dorsally, dorsal seta $18 \mu \mathrm{m}$, both smooth. Outermost terminal seta $47 \mu \mathrm{m}$, innermost terminal seta $70 \mu \mathrm{m}$, and 2 median terminal setae $109 \mu \mathrm{m}$ (outer) and $135 \mu \mathrm{m}$ (inner); all 4 terminal setae with lateral setules. Ramus having small terminal ventral flange.

Ventral area between maxillipeds and first pair of legs with median protuberance (Fig. 13a) as in congeners.

Body surface with sensilla as in Fig. 13a, b. Cephalosome with lateral sclerotized network as in Fig. 13a.

Egg sac not seen.

Rostral area undeveloped. First antenna (Fig. 13f) 20-segmented, $242 \mu \mathrm{m}$ long, with armature as in C. comanthiphilus and other congeners. Aesthete on antepenultimate segment $68 \mu \mathrm{m}$. Second antenna (Fig. 13g) $104 \mu \mathrm{m}$ long without clawlike seta $39 \mu \mathrm{m}$. Fourth segment with few minute spinules distally and very small inner spine proximally.

Oral cone similar to that of $C$. comanthiphilus and other congeners.

Mandible (Fig. 13h) with seta on basal part, blade $68 \mu \mathrm{m}$ with few terminal teeth. First maxilla (Fig. 14a) with long seta on outer lobe. Second maxilla (Fig. 14b) with second segment of claw having few small terminal spinules. Short hyaline seta (?) near insertion of second maxilla. Maxilliped (Fig. 14c) similar to that in congeners. Seta on second segment very small. Claw $42 \mu \mathrm{m}$.

Legs 1-4 (Fig. 14d, e, f, g) with segmentation and armature like that of C. comanthiphilus and other congeners. Basis of legs 1 and 2 with small crescentic sclerotization on posterior surface (Fig. 14d, e).

Leg 5 (Fig. 14h) 2-segmented. First segment expanded as inner triangular lobe with very small spinuliform tip and bearing dorsal seta $36 \mu \mathrm{m}$. Second segment $47 \times 11 \mu \mathrm{m}$, its 4 setae from outer to inner $8,29,15$, and $17 \mu \mathrm{m}$.

Leg 6 probably represented by small seta and spine on genital area (Fig. 13d). Color of living specimens unknown.

Male. Body (Fig. 15a) flexed as in female. Length $0.51 \mathrm{~mm}(0.51-0.52 \mathrm{~mm})$ 


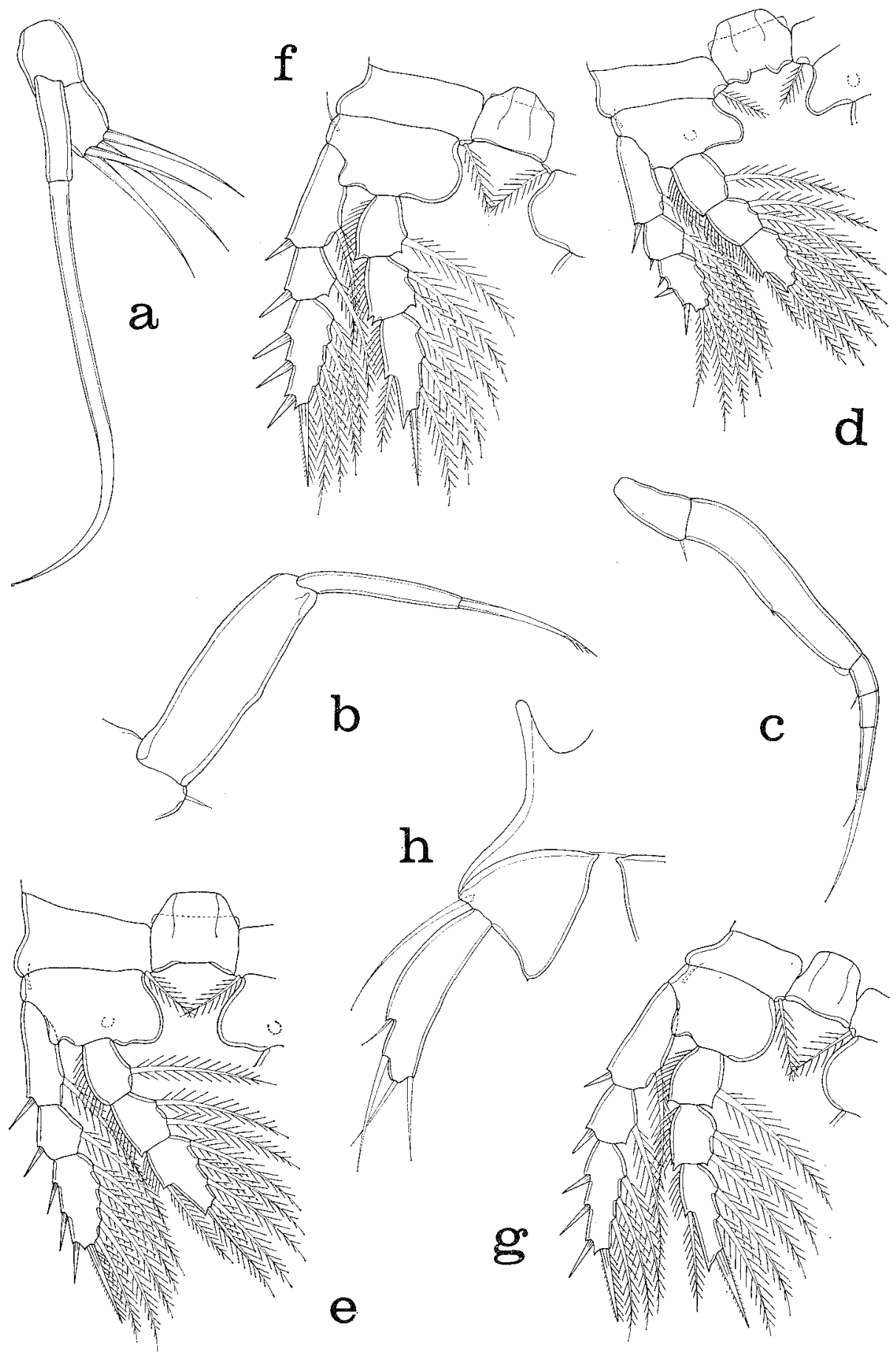

Fig. 14. Collocheres thysanotus, new species, female. a, first maxilla (scale D); b, second maxilla, posterior $(\mathrm{D})$; c, maxilliped, posterior $(\mathrm{F})$; d, leg 1 and intercoxal plate, anterior $(\mathrm{F})$; e, leg 2 and intercoxal plate, anterior (F); $f$, leg 3 and intercoxal plate, anterior (F); g, leg 4 and intercoxal plate, anterior (F); h, leg 5 , ventral (F). 
and greatest width $0.14 \mathrm{~mm}(0.13-0.14 \mathrm{~mm})$, based on 5 specimens. Dorsoventral thickness at level of ventral protuberance $138 \mu \mathrm{m}$. Ratio of length to width of prosome 2.27:1. Ratio of length of prosome to that of urosome 1.47:1.

Segment bearing leg 5 (Fig. 15b) $39 \times 57 \mu \mathrm{m}$. Genital segment wider than long, $55 \times 73 \mu \mathrm{m}$, with anterior "shoulders" and only slightly rounded lateral margins. Four postgenital segments from anterior to posterior $39 \times 50,32 \times 42,18 \times 34$, and $19 \times 36 \mu \mathrm{m}$. First 2 postgenital segments with spiniform processes and ventral lobed fringe as in female.

Caudal ramus (Fig. 15b) $26 \times 18 \mu \mathrm{m}$, ratio $1.44: 1$.

Body surface as in female.

Rostral surface undeveloped as in female. First antenna (Fig. 15c) geniculate, 18-segmented, and armed as in congeners. Ninth segment expanded. Hyaline "joint" between segments 16 and 17. Second antenna, oral cone, mandible, first maxilla, second maxilla, maxilliped, and legs $1-4$ as in female.

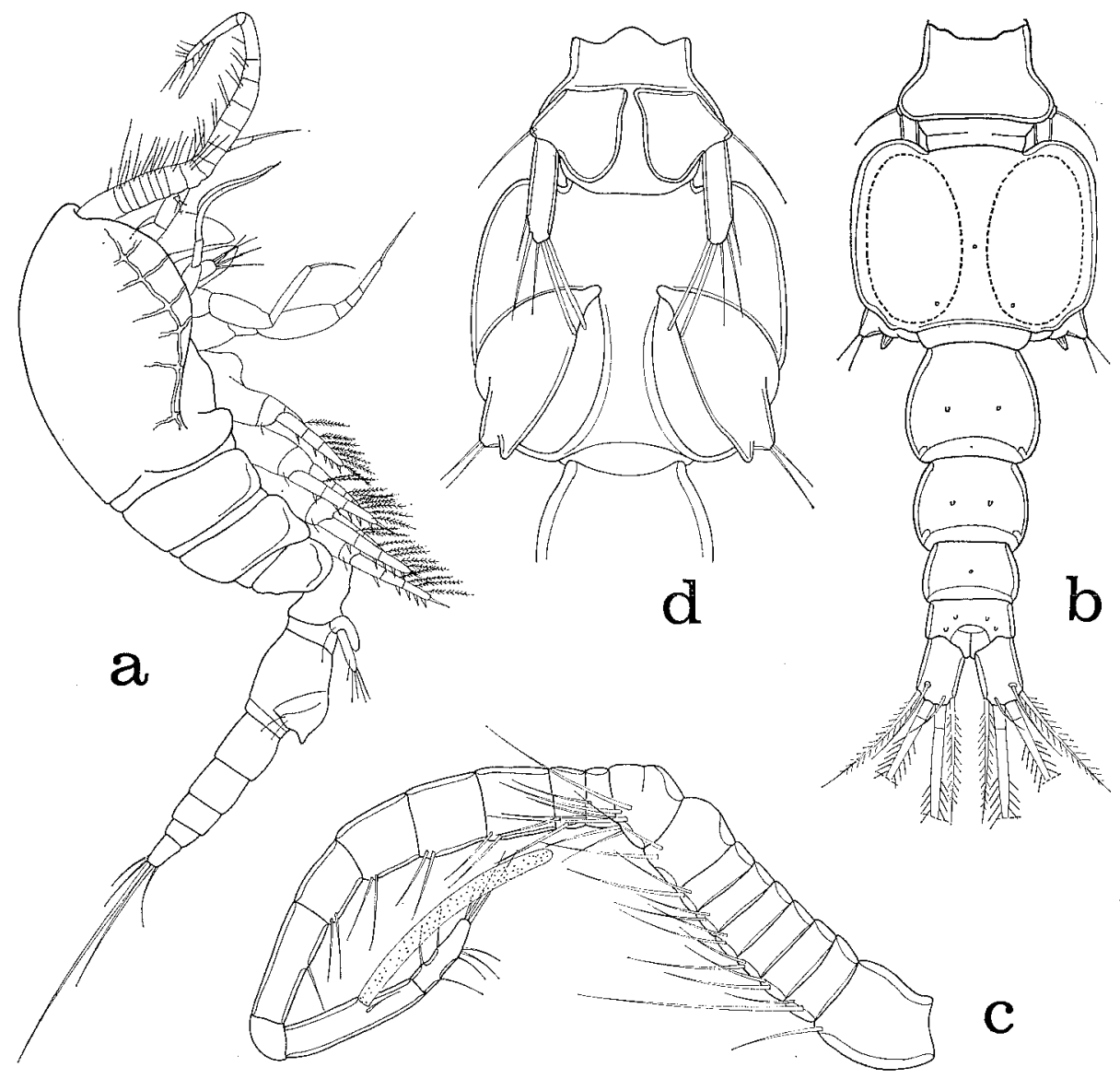

Fig. 15. Collocheres thysanotus, new species, male. a, lateral (scale E); b, urosome, dorsal (C); c, first antenna, ventral (D); d, segment bearing leg 5 and genital segment, showing leg 5 and $\operatorname{leg} 6$, ventral $(\mathrm{F})$. 
Leg 5 (Fig. 15d) with second segment $31 \times 9 \mu \mathrm{m}$, bearing 5 setae, 2 inner of these hyaline and broad, $21 \mu \mathrm{m}$ long.

Leg 6 (Fig. 15d) with 2 spiniform processes and 2 small setae.

Spermatophore not seen.

Color unknown.

Etymology. The specific name thysanotus, Greek meaning fringed, refers to the ventral hyaline lobed fringe on the posterior margin of certain urosomal segments.

Remarks. Collocheres thysanotus differs from congeners in the following ways: (1) the caudal ramus in the female having the ratio $1.7: 1$, (2) the genital and postgenital segments of the female having a posteroventral hyaline lobed fringe, (3) the exopod of the first maxilla having a long seta, four times the length of the segment, and (4) the free segment of leg 5 in the female with the ratio 4.5:1.

\section{Collocheres marginatus, new species}

(Figs 16-18)

Type material. $30 \% q, 9 \widehat{\delta}$, from 1 crinoid, Comanthina variabilis (Bell), in 9-10 m, reef north of East Point, Darwin, Northern Territory, Australia, $12^{\circ} 24^{\prime} 02^{\prime \prime} \mathrm{S}, 130^{\circ} 49^{\prime} 00^{\prime \prime} \mathrm{E}, 4$ March 1986, C. Johnson collector. Holotype , allotype, and 16 paratypes (13우, $3 \delta^{\circ}$ ) deposited in the Northern Territory Museum, Darwin; 15 paratypes $\left(12 q q, 30^{\star}{ }^{\circ}\right)$ in the National Museum of Natural History, Smithsonian Institution, Washington, D.C.

Other specimens. From Comanthina variabilis: $69+9,7 \hat{\mathrm{o}}$, from 1 host, type locality, same date; $4 ㅇ ㅜ, 20^{x}$, from 1 host, same locality and date; 2 웅, $30^{\star} \hat{0}$, from 1 host, same locality and date.

Female. Body (Fig. 16a) similar to that of congeners. Length $0.77 \mathrm{~mm}(0.75-$ $0.80 \mathrm{~mm}$ ) and greatest width $0.22 \mathrm{~mm}$, based on 10 specimens. Dorsoventral thickness at level of ventral protuberance in front of first pair of legs $223 \mu \mathrm{m}$. Segmentation of prosome well developed. Ratio of length to width of prosome 2:1. Ratio of length of prosome to that of urosome $1.56: 1$.

Segment bearing leg 5 (Fig. 16b) $62 \times 73 \mu \mathrm{m}$. Genital segment elongate, $120 \times$ $78 \mu \mathrm{m}$, widest in anterior third at level of genital areas, and having several small lateral transverse sclerotized ridges. Each genital area with small spine and seta (Fig. 16c). Three postgenital segments from anterior to posterior $44 \times 47,29 \times 42$, and $26 \times 37 \mu \mathrm{m}$.

Caudal ramus (Fig. 16d) moderately short, $38 \times 19 \mu \mathrm{m}$, ratio 2:1. Outer lateral seta $70 \mu \mathrm{m}$ and displaced dorsally, dorsal seta $26 \mu \mathrm{m}$, both smooth. Outermost terminal seta $65 \mu \mathrm{m}$, innermost terminal seta $99 \mu \mathrm{m}$, and 2 median terminal setae $160 \mu \mathrm{m}$ (outer) and $260 \mu \mathrm{m}$ (inner); all 4 terminal setae with lateral setules. Ramus with minute terminal ventral flange.

Ventral area between maxillipeds and first pair of legs with median protuberance (Fig. 16a) less pronounced than in other species.

Body surface with sensilla as in Fig. 16b. Gephalosome with sclerotized network as in Fig. 16a. 


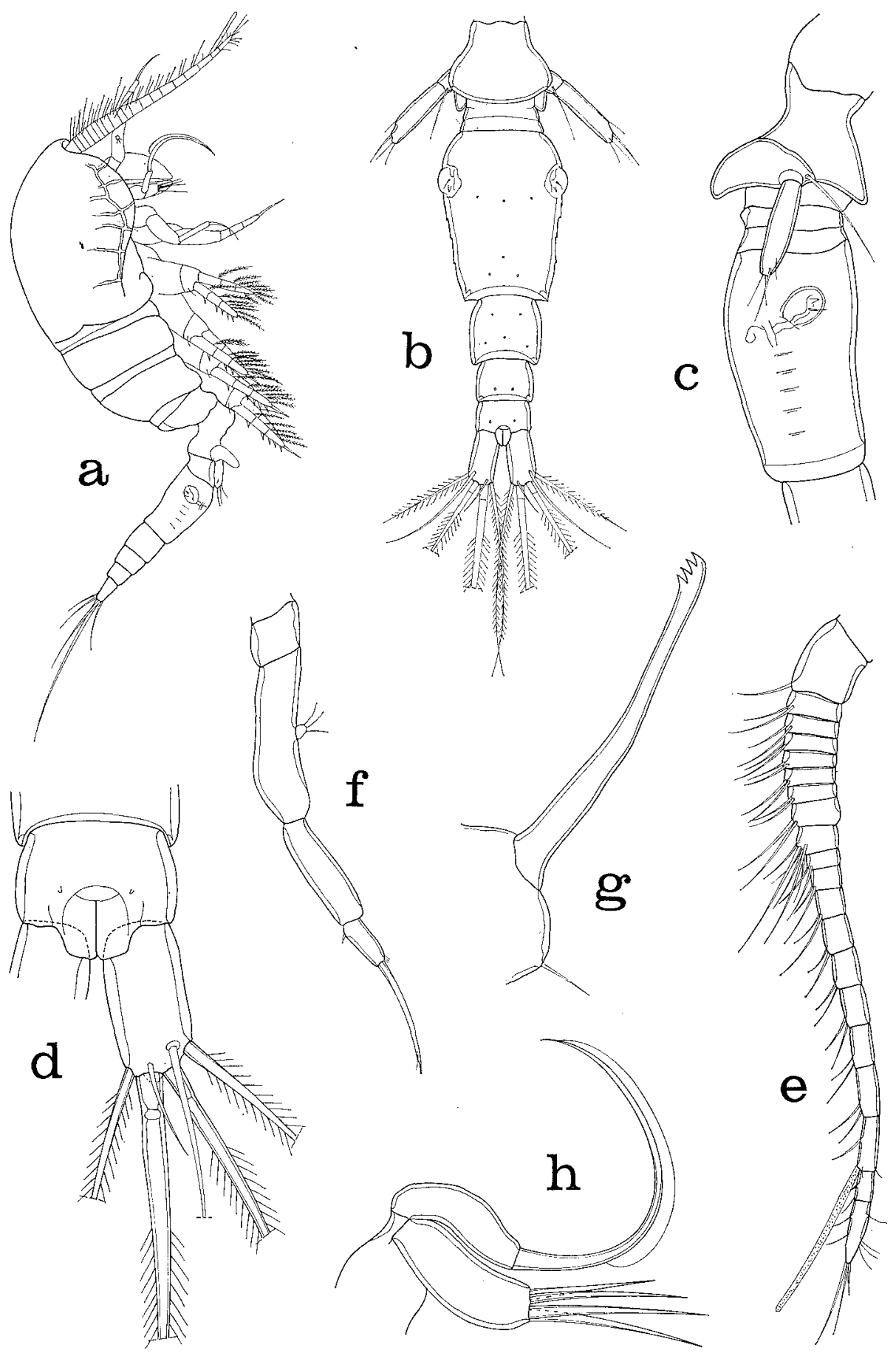

Fig. 16. Collocheres marginatus, new species, female. a, lateral (scale A); b, urosome, dorsal (B); c, segment bearing leg 5 and genital segment, lateral $(B)$; d, anal segment and caudal ramus, dorsal (D); e, first antenna, ventral (C); f, second antenna, posterior $(\mathrm{F})$; g, mandible, anterior (D); h, first maxilla, anteroventral (D). 
Egg sac containing cluster of 5-7 eggs.

Rostral area not developed. First antenna (Fig. 16e) 20-segmented, $309 \mu \mathrm{m}$ long, with armature as in congeners. Aesthete on antepenultimate segment $68 \mu \mathrm{m}$. Second antenna (Fig. 16f) $125 \mu \mathrm{m}$ long without clawlike seta $42 \mu \mathrm{m}$. Fourth segment with very small inner proximal spine and few distal minute spinules. Clawlike seta with very small subterminal setule.

Oral cone resembling that of $C$. comanthiphilus and other species.

Mandible (Fig. 16g) with basal part bearing short seta (palp ?) approximately $14 \mu \mathrm{m}$. Blade of mandible $87 \mu \mathrm{m}$ with 4 terminal teeth. First maxilla (Fig. 16h) of usual form for genus, but seta on outer lobe long and unilaterally with prominent broad hyaline membrane. Second maxilla (Fig. 17a) resembling that of congeners. Second segment of claw with few small terminal spinules. Small hyaline seta (?) near insertion of second maxilla. Maxilliped (Fig. 16b) of usual form in congeners. Claw $49 \mu \mathrm{m}$ with minute outer subterminal knob.

Legs 1-4 (Fig. 17c, d, e, f) segmented and armed as in C. comanthiphilus and other congeners.

Leg 5 (Fig. 17g) 2-segmented. First segment bearing dorsal seta $42 \mu \mathrm{m}$ and expanded as inner lobe with broadly rounded tip. Second segment $54 \times 13 \mu \mathrm{m}$, its 4 setae from outer to inner 15, 24, 34, and $24 \mu \mathrm{m}$.

Leg 6 probably represented by small spine and seta on genital area (Fig. 17c).

Color of living specimens unknown. Caudal ramus slightly brownish in specimens preserved in ethyl alcohol.

Male. Body (Fig. 18a) resembling that of female in general form. Length 0.60 $\mathrm{mm}(0.58-0.62 \mathrm{~mm})$ and greatest width $0.18 \mathrm{~mm}$, based on 10 specimens. Dorsoventral thickness at level of ventral protuberance $156 \mu \mathrm{m}$. Ratio of length to width of prosome 2.14:1. Ratio of length of prosome to that of urosome 1.25:1.

Segment bearing leg 5 (Fig. 18b) $39 \times 55 \mu \mathrm{m}$. Genital segment subquadrate, $83 \times 94 \mu \mathrm{m}$, with slight anterior "shoulders". Four postgenital segments from anterior to posterior $44 \times 52,36 \times 42,23 \times 26$, and $22 \times 35 \mu \mathrm{m}$.

Caudal ramus (Fig. 18b) resembling that of female but smaller, $26 \times 16 \mu \mathrm{m}$, ratio $1.6: 1$.

Body surface as in female.

Rostral area not developed. First antenna (Fig. 18c) geniculate, 18-segmented, and armed as in congeners. Hyaline "joint" between segments 16 and 17. Aesthete $73 \mu \mathrm{m}$. Second antenna, oral cone, mandible, first maxilla, second maxilla, maxilliped, and legs $1-4$ as in female.

Leg 5 (Fig. 18d) with free segment $31 \times 8 \mu \mathrm{m}$, bearing 5 setae, inner 2 rodlike and hyaline, from outer to inner $13,25,20,30$, and $30 \mu \mathrm{m}$.

Leg 6 (Fig. 18d) with 2 processes, one bearing 2 small setae, other bluntly conical.

Extruded spermatophore not seen.

Color unknown, except caudal ramus slightly brownish as in female.

Etymology. The specific name marginatus, Latin meaning having a border, 


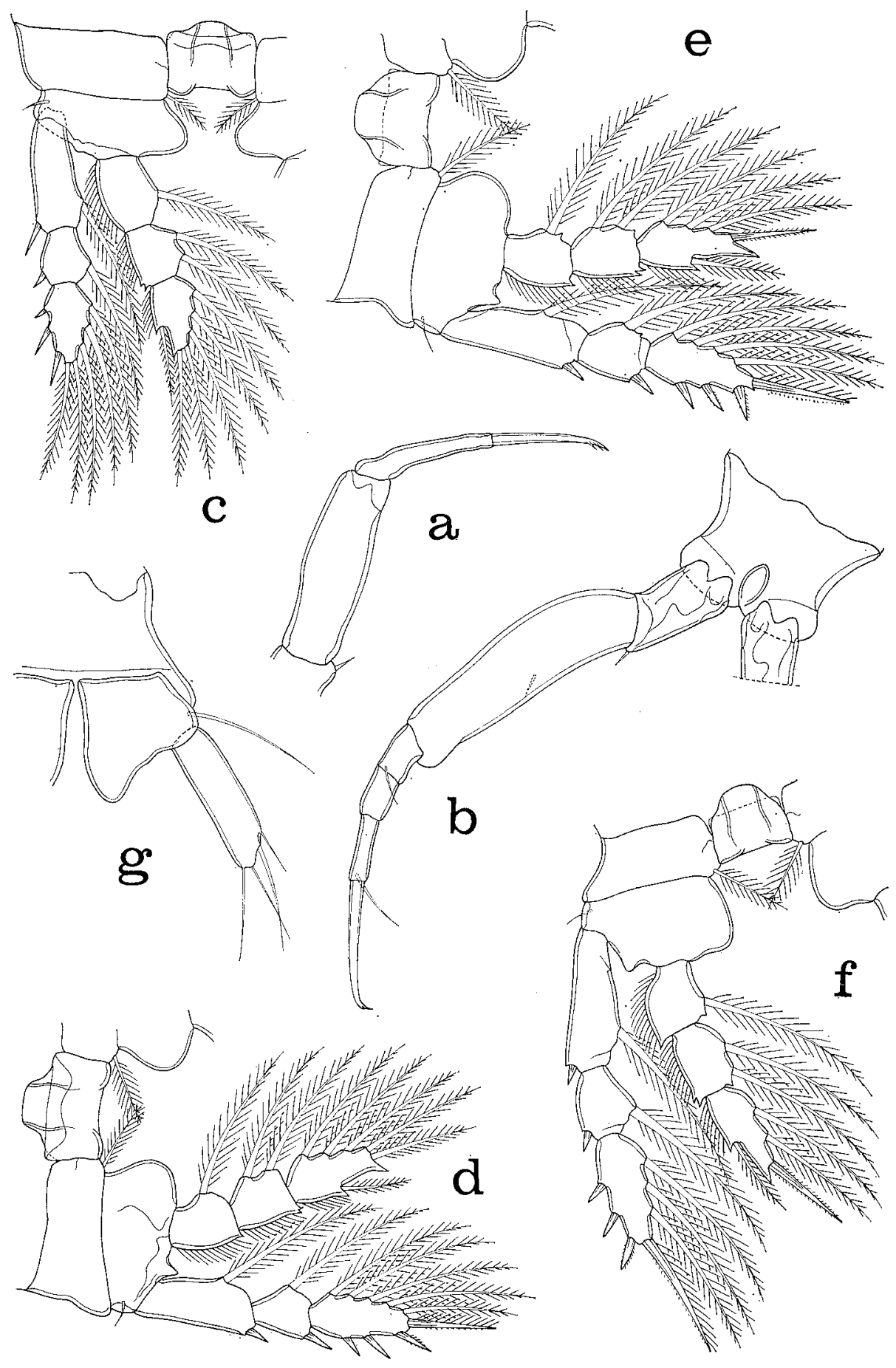

Fig. 17. Collocheres marginatus, new species, female. a, second maxilla, posterior (scale F); b, maxilliped, posterior $(F)$; c, leg 1 and intercoxal plate, posterior $(F) ; d, \operatorname{leg} 2$ and intercoxal plate, posterior $(F)$; e, leg 3 and intercoxal plate, anterior $(F) ; f, l e g ~ 4$ and intercoxal plate, anterior $(\mathbf{F}) ; \mathrm{g}, \operatorname{leg} 5$, ventral $(\mathrm{F})$. 


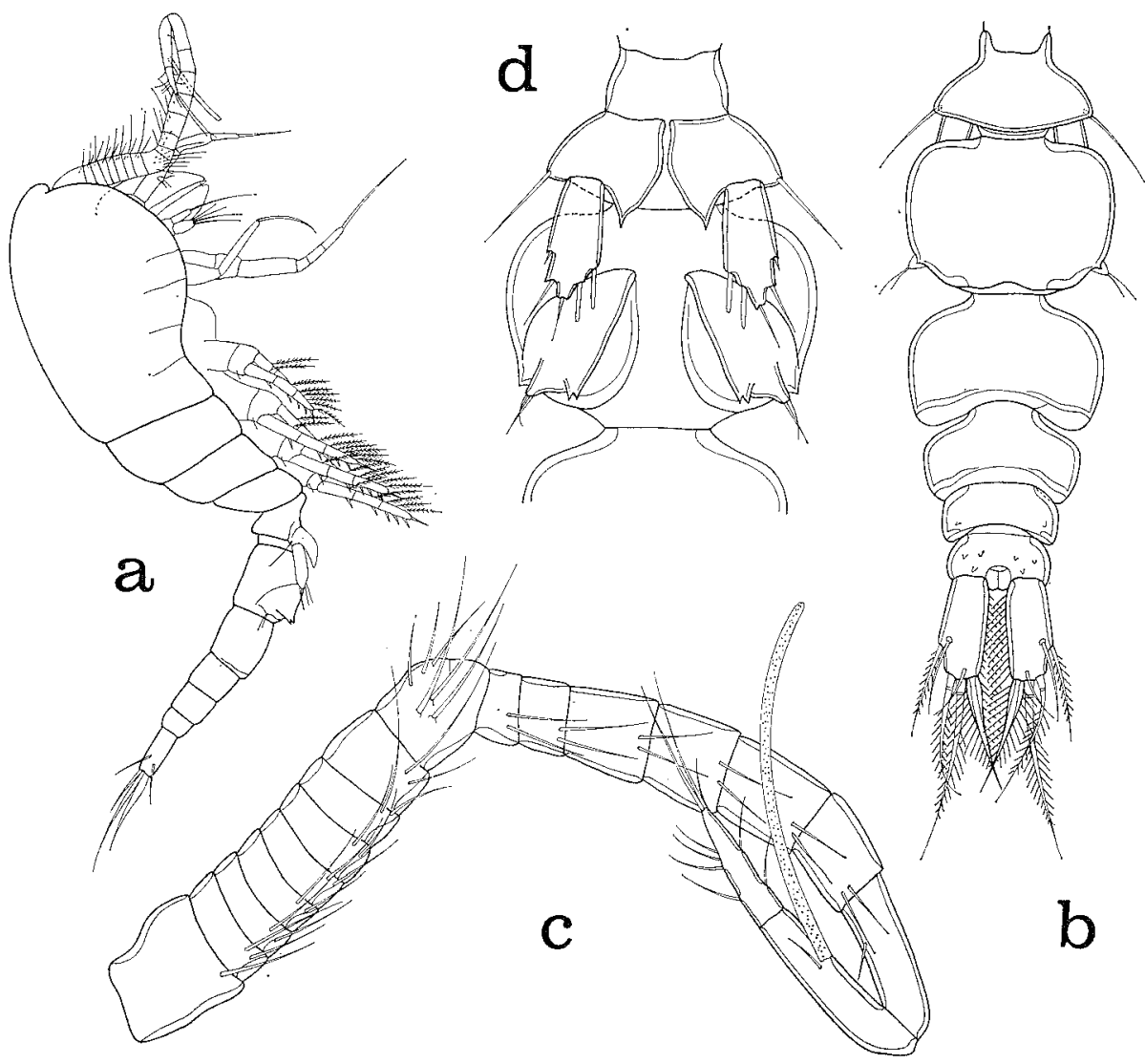

Fig. 18. Collocheres marginatus, new species, male. a, lateral (scale E); b, urosome, dorsal (C); c, first antenna, ventral $(F)$; d, segment bearing leg 5 and genital segment, showing leg 5 and $\operatorname{leg} 6$, ventral $(\mathrm{F})$.

alludes to the membrane on the seta of the exopod of the first maxilla.

Remarks. This species may be distinguished by the broad hyaline lamella on the long seta on the exopod of the first maxilla. The caudal ramus of the female is short, ratio 2:1. The distal segment of leg 5 in the female is elongate, ratio 4.15:1.

Key to the Indo-Pacific species of Collocheres, based on females (omitting the insufficiently described $C$. giesbrechti

Thompson \& A. Scott, 1903)

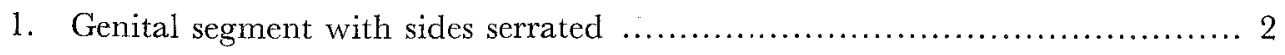

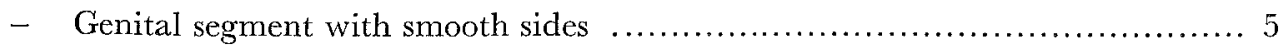

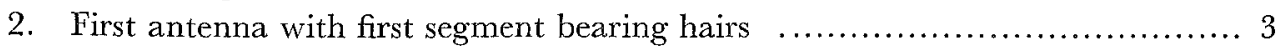

- First antenna with first segment smooth .................................. 4

3. Leg 5 with free segment having 4 nearly equal setae ................ uncinatus 
- Leg 5 with free segment having 4 setae but proximo-outer seta very short C. inaequalis

4. Caudal ramus $3.2: 1$; first maxilla with short seta without lamella on outer lobe C. serrulatus

- Caudal ramus 2:1; first maxilla having long seta with broad hyaline lamella on outer lobe

C. marginatus

5. Average length of body less than $5 \mathrm{~mm}(0.45 \mathrm{~mm}$, range $0.43-0.57 \mathrm{~mm}$ )

C. parvus

- Average length of body more than $6 \mathrm{~mm}(0.62-0.77 \mathrm{~mm}$, range $0.58-0.81 \mathrm{~mm}$ )

6. Seta on outer lobe of first maxilla long, 3 or 4 times length of segment

- Seta on outer lobe of first maxilla short, only 1.6 times length

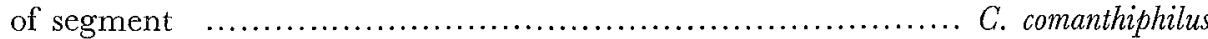

7. Long slender terminal setae on second antenna, second maxilla, and maxilliped; ratio of terminal seta on second antenna to entire 4 segments $1: 1.56$

- Terminal setae on second antenna, second maxilla, and maxilliped not unusually long; ratio of terminal seta on second antenna to entire 4 segments approximately $1: 3$ or less

8. Innermost terminal seta on caudal ramus swollen proximally; caudal ramus 2.35:1; genital and postgenital segments without posteroventral fringe C. inflatiseta

- Innermost terminal seta on caudal ramus not swollen proximally; caudal ramus $1.7: 1$; genital and postgenital segments with posteroventral fringe C. thysanotus

\section{Glyptocheres, new genus}

Diagnosis. Asterocheridae. Body slender, not modified or transformed. Genital segment in female and first postgenital segment in male with conspicuous posterolateral processes. Caudal ramus with outer lateral seta placed dorsally and dorsal seta arising subterminally.

Rostrum undeveloped. First antenna 20-segmented, with aesthete on antepenultimate segment. Second antenna with 1-segmented exopod. Oral cone short, no true siphon. Mandible with small setiform palp and long slender blade toothed at tip. First maxilla, second maxilla, and maxilliped similar in general form to those of Collocheres and Collocherides.

Legs 1-4 biramous with 3-segmented rami. Formula for armature as in Collocheres.

Leg 5 2-segmented, with basal segment bearing 1 lateral seta and produced medially. Distal segment elongate with 4 setae in female, 4 setae and 2 lanceolate setae in male. 
Leg 6 with 2 small elements.

Egg sac as far as known with 4 or 5 eggs.

Type species. Glyptocheres extrusus, new species.

Etymology. The generic name is a combination of Greek glyptos, carved, and cheres, a frequent combining form in siphonostomatoid copepods.

\section{Glyptocheres extrusus, new species}

(Figs 19, 20)

Type material. 165우우, 59ðð, from 1 crinoid, Comanthus bennetti (J.H. Müller), in $40 \mathrm{~m}$, Bohol Island, Philippines, $10^{\circ} 17.9^{\prime} \mathrm{N}, 124^{\circ} 10.9^{\prime} \mathrm{E}, 22$ September 1975, Thomas Forhan collector. Holotype $q$, allotype, and 217 paratypes $\left(16190,560^{\star}\right)$ deposited in the National Museum of Natural History, Smithsonian Institution, Washington, D.C.

Other specimens. From Comanthus bennelti: 201우, 104 3 , from 1 host, in $12 \mathrm{~m}$, Mermaid Cove,

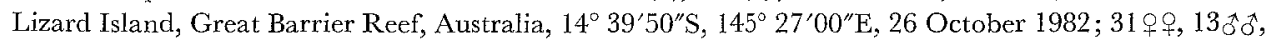
from 3 hosts, in $4 \mathrm{~m}$, southwestern shore of Goenoeng Api, Banda Islands, Moluccas, $04^{\circ} 31^{\prime} 45^{\prime \prime} \mathrm{S}, 129^{\circ}$

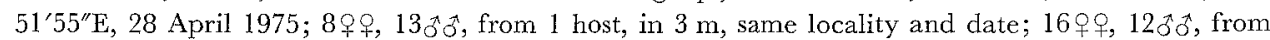
1 host, in $4 \mathrm{~m}$, same locality and date; 4 우우 1000 , from 1 host, in $4 \mathrm{~m}$, same locality and date; 3 우,

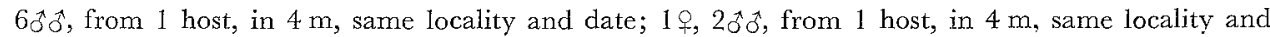

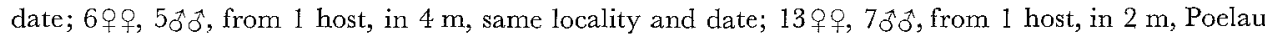
Marsegoe, Moluccas, $02^{\circ} 59^{\prime} 30^{\prime \prime} \mathrm{S}, 128^{\circ} 03^{\prime} 30^{\prime \prime} \mathrm{E}, 15$ May $1975 ; 52$ \% 9 , 29 $\hat{o}^{\circ} \hat{o}$, from 1 host, Poelau Gomumu, south of Obi, Moluccas, $01^{\circ} 50^{\prime} 00^{\prime \prime} \mathrm{S}, 127^{\circ} 30^{\prime} 44^{\prime \prime} \mathrm{E}, 30 \mathrm{May} 1975$. From ? Comanthus parvicirrus (J. Müller) (approximates to Comanthina): 399, from 1 host, in $1.5 \mathrm{~m}$, Ricaudy Reef, Noumea, New Caledonia, 22 $2^{\circ} 19^{\prime} 00^{\prime \prime} \mathrm{S}, 166^{\circ} 27^{\prime} 18^{\prime \prime} \mathrm{E}, 18 \mathrm{June}$ 1971. From Comanthus samoanus A.H. Clark: 104 우우 $14 \delta^{3}$, from 1 host, in $25 \mathrm{~m}$, southern shore of Goenoeng Api, Banda Islands, Moluccas, $04^{\circ}$ $32^{\prime} 05^{\prime \prime} \mathrm{S}, 129^{\circ} 52^{\prime} 30^{\prime \prime} \mathrm{E}, 26$ April 1975.

Female. Body (Fig. 19a) resembling that of Collocheres comanthiphilus. Length $0.73 \mathrm{~mm}(0.69-0.77 \mathrm{~mm})$ and greatest width $0.20 \mathrm{~mm}(0.16-0.22 \mathrm{~mm})$, based on 10 specimens. Dorsoventral thickness and ratios of prosome and urosome as in $C$. comanthiphilus.

Segment of $\operatorname{leg} 5$ (Fig. 19b) $70 \times 94 \mu \mathrm{m}$. Genital segment elongate, $112 \mu \mathrm{m}$ long without posterolateral processes, $146 \mu \mathrm{m}$ with these processes, $94 \mu \mathrm{m}$ wide in anterior third, and $97 \mu \mathrm{m}$ wide in posterior third. Genital areas located anteriorly and having seta and small spine. Small spiniform process located on lateral margins of segment in posterior third. Posterolateral corners of segment with prominent protrusions (Fig. 19c, d). Three postgenital segments from anterior to posterior $60 \times 57,39 \times 48$, and $26 \times 47 \mu \mathrm{m}$. Anal segment with 2 pairs of sensilla on dorsal surface (Fig. 19e).

Caudal ramus (Fig. 19e) moderately elongate, $55 \times 24 \mu \mathrm{m}$, ratio 2.29:1. Outer lateral seta, placed a little dorsally, $55 \mu \mathrm{m}$, dorsal seta $33 \mu \mathrm{m}$, both smooth. Outermost terminal seta displaced subterminally, $73 \mu \mathrm{m}$, innermost terminal seta $84 \mu \mathrm{m}$, 2 median terminal setae $117 \mu \mathrm{m}$ (outer) and $133 \mu \mathrm{m}$ (inner), all these setae with lateral hairs.

Body surface lacking sensilla except for those on anal segment. 


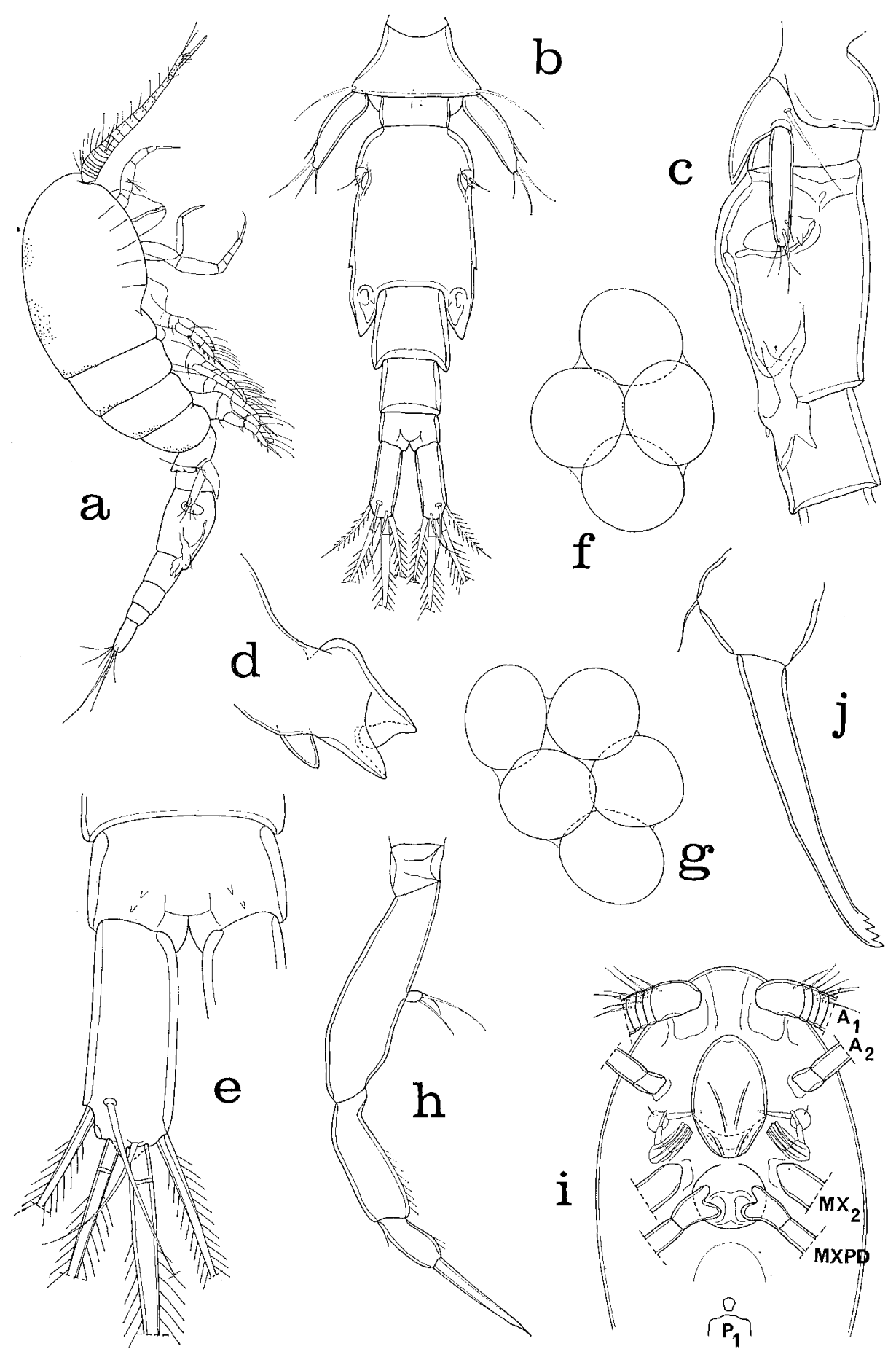

Fig. 19. Glyptocheres extrusus, new genus, new species, female. a, lateral (scale A); b, urosome, dorsal (B); c, segment bearing leg 5, genital segment, and first postgenital segment, lateral (C); d, posterolateral processes on genital segment, lateral (D); e, anal segment and caudal ramus, dorsal $(D) ; f$, egg sac, lateral $(E)$; g, egg sac, lateral $(E) ; h$, second antenna, anteroventral (D); i, cephalosome, ventral (B); j, mandible, posterior (D). 


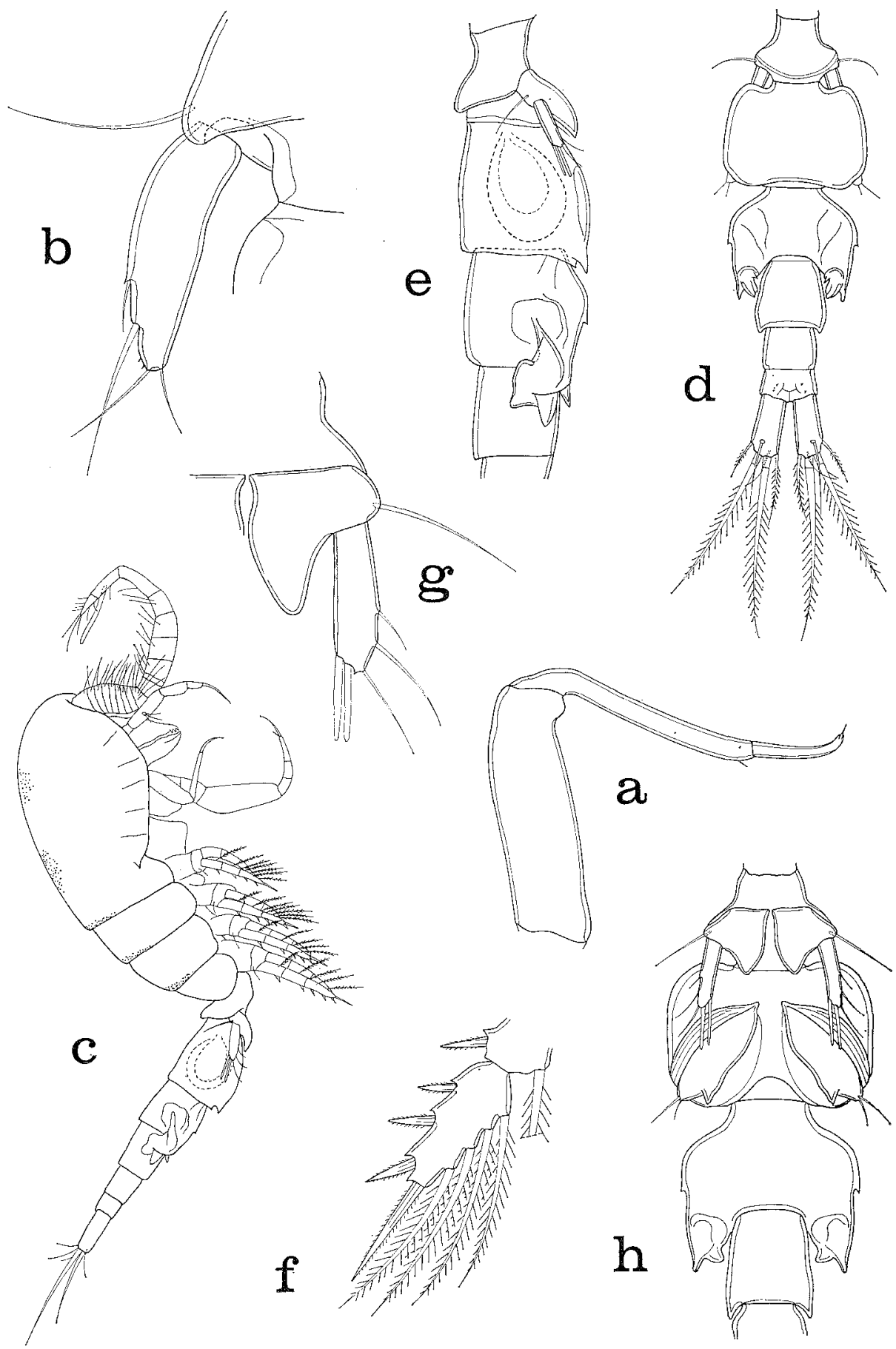

Fig. 20. Glyptocheres extrusus, new genus, new species. Female. a, second maxilla, anterior (scale D); b, leg 5, dorsal (D). Male. c, lateral (E); d, urosome, dorsal (B); e, segment bearing leg 5 , genital segment, and first two postgenital segments, lateral (B); $f$, abnormal third segment of exopod of leg 3, anterior (D); g, leg 5, ventral (D); h, segment bearing leg 5 , genital segment, and first two postgenital segments, ventral $(\mathbf{C})$. 
Egg sac with 4 eggs (Fig. 19f), $253 \times 192 \mu \mathrm{m}$, or 5 eggs (Fig. 19g), $275 \times 185$ $\mu \mathrm{m}$. Egg diameter $91-109 \mu \mathrm{m}$.

Rostral area and first antenna very similar to those in C. comanthiphilus. Second antenna (Fig. 19h) resembling that of C. comanthiphilus in major respects.

Oral cone (Fig. 19a, i) less truncated posteriorly than in C. comanthiphilus. Mandible (Fig. 19j), first maxilla, second maxilla (Fig. 20a), maxilliped, postoral area, and legs 1-4 resembling those of $C$. comanthiphilus.

Leg 5 (Fig. 20b) similar to that of $C$. comanthiphilus. First segment with outer seta $55 \mu \mathrm{m}$ and triangular flap (not visible in dorsal view), second segment $60 \times 7$ $\mu \mathrm{m}$, its setae $11,42,31$, and $23 \mu \mathrm{m}$ from outer to inner. Two minute outer spinules near outer 2 terminal setae.

Color of living specimens unknown, but specimens in ethyl alcohol light bluish gray.

Male. Body (Fig. 20c) resembling that of C. comanthiphilus. Length $0.60 \mathrm{~mm}$ $(0.56-0.68 \mathrm{~mm})$ and greatest width $0.15 \mathrm{~mm}(0.14-0.16 \mathrm{~mm})$, based on 10 specimens.

Segment of leg 5 (Fig. 20d) $39 \times 65 \mu \mathrm{m}$. Genital segment $73 \times 104 \mu \mathrm{m}$. First postgenital segment $52 \mu \mathrm{m}$ long in midline, $81 \mu \mathrm{m}$ long including posterolateral processes, $86 \mu \mathrm{m}$ wide. Small spiniform process on lateral margins of segment. Posterolateral corners of segment with conspicuous processes (Fig. 20e, h) resembling those of female. Second, third, and fourth postgenital segments $50 \times 47,34 \times 39$, and $25 \times 40 \mu \mathrm{m}$, respectively.

Caudal ramus as in female but smaller, $42 \times 21 \mu \mathrm{m}$, ratio $2: 1$.

Rostral area as in female. First antenna similar to that of male of $C$. comanthiphilus. Second antenna, oral cone, mandible, first maxilla, second maxilla, maxilliped, postoral area, and legs 1-4 like those of $C$. comanthiphilus. One female with third exopod segment of leg 3 having 4 inner setae (Fig. 20f), instead of usual 3.

Leg 5 (Fig. 20g) with outer seta on first segment $37 \mu \mathrm{m}$. Second segment $36 \times$ $11 \mu \mathrm{m}$, with 3 outer setae 8,27 , and $21 \mu \mathrm{m}$, and 2 broad inner setae $22 \mu \mathrm{m}$ and 23 $\mu \mathrm{m}$.

Leg 6 (Fig. 20h) with 2 small setae and spiniform process.

Spermatophore not seen.

Color as in female.

Etymology. The specific name extrusus, past participle of extrudo, meaning to extrude, alludes to the posterolateral processes on the genital segment of the female and on the first postgenital segment of the male, appearing as if they had been extruded from the segment.

\section{Glyptocheres comanthinae, new species}

(Figs 21, 22)

Type material. 79우, 330ิ0, from I crinoid, Comanttina schlegeli (P.H. Carpenter), in $4 \mathrm{~m}$, southwestern shore of Goenoeng Api, Banda Islands, Moluccas, 04 $31^{\prime} 45^{\prime \prime} \mathrm{S}, 129^{\circ} 51^{\prime} 55^{\prime \prime} \mathrm{E}, 28$ April 1975. 
Holotype $q$, allotype, and 99 paratypes $(69+q, 30 \hat{\circ})$ deposited in the National Museum of Natural History, Smithsonian Institution, Washington, D.C.

Female. Body form similar to that of Glyptocheres extrusus (Fig. 19a). Length $0.67 \mathrm{~mm}(0.61-0.72 \mathrm{~mm})$ and greatest width $0.21 \mathrm{~mm}(0.21-0.22 \mathrm{~mm})$, based on 10 specimens. Greatest dorsoventral thickness at level of protuberance on ventral surface in front of first pair of legs $0.20 \mathrm{~mm}$.

Segment bearing leg 5 (Fig. 21a) $65 \times 78 \mu \mathrm{m}$. Genital segment $91 \mu \mathrm{m}$ long without posterolateral processes, $148 \mu \mathrm{m}$ with these processes, $81 \mu \mathrm{m}$ wide in anterior third, $94 \mu \mathrm{m}$ wide in posterior two-thirds. Genital areas located laterally in anterior third and bearing small spine and seta (Fig. 2Ib). Small spiniform process on lateral margin of segment at level of greatest width. Posterolateral corners of segment with large protrusions (Fig. 2la, b). Three postgenital segments from anterior to posterior $49 \times 52,34 \times 44$, and $28 \times 44 \mu \mathrm{m}$.

Caudal ramus (Fig. 21c) $36 \times 22 \mu \mathrm{m}$, ratio 1.64:1. Outer lateral seta, placed dorsally, $47 \mu \mathrm{m}$, dorsal seta $33 \mu \mathrm{m}$, both smooth. Outermost terminal seta, displaced subterminally, $60 \mu \mathrm{m}$, innermost terminal seta $90 \mu \mathrm{m}$, and 2 median terminal setae $109 \mu \mathrm{m}$ (outer) and $133 \mu \mathrm{m}$ (inner), all these setae with lateral hairs.

Body surface without sensilla except for few refractile knobs on dorsal surface of genital and postgenital segments (Fig. 21a).

Egg sac seen only as empty sac, but in 5 females empty egg sacs still attached to genital areas.

Rostral area like that of Collocheres comanthiphilus. First antenna $263 \mu \mathrm{m}$ long, aesthete $65 \mu \mathrm{m}$, otherwise as in C. comanthiphilus. Second antenna as in Fig. 21d.

Oral cone (Fig. 21g) as in Glyptocheres extrusus. Mandible (Fig. 21e) with basal portion having small hyaline setiform palp and slender blade $73 \mu \mathrm{m}$ long. First maxilla (Fig. 21f) with inner lobe bearing 4 setae and outer lobe having very long stout seta, estimated length $125 \mu \mathrm{m}$ or 5.5 times length of outer lobe, this long seta extending conspicuously in lateral view of cephalosome (Fig. $21 \mathrm{~g}$ ). Second maxilla as in Fig. 21h. Maxilliped (Fig. 22a) 5-segmented, with claw $37 \mu \mathrm{m}$.

Legs 1-4 resembling those of $C$. comanthiphilus and $G$. extrusus, but inner margin of basis of leg 1 a little more truncate (Fig. 22b) than in G. extrusus.

Leg 5 (Fig. 22c) with first segment having inner triangular flap with bluntly rounded tip and bearing outer seta $34 \mu \mathrm{m}$. Second segment $47 \times 15.5 \mu \mathrm{m}$, its 4 setae $4,31,18$, and $33 \mu \mathrm{m}$ from outer to inner.

Color of living specimens amber, eye red.

Male. Body form like that of G. extrusus (Fig. 20c). Length $0.49 \mathrm{~mm}(0.47-$ $0.51 \mathrm{~mm})$ and greatest width $0.14 \mathrm{~mm}(0.13-0.14 \mathrm{~mm})$, based on 10 specimens. Greatest dorsoventral thickness at level of ventral protuberance $0.18 \mathrm{~mm}$.

Segment bearing leg 5 (Fig. 22d) $26 \times 55 \mu \mathrm{m}$. Genital segment $55 \times 83 \mu \mathrm{m}$, wider than long. First postgenital segment also wider than long, $80 \mu \mathrm{m}$ wide, $39 \mu \mathrm{m}$ long in midline, $65 \mu \mathrm{m}$ long including posterolateral processes, resembling those of female. Second, third, and fourth postgenital segments $39 \times 42,26 \times 37$, and $18 \times 38$ $\mu \mathrm{m}$, respectively. 

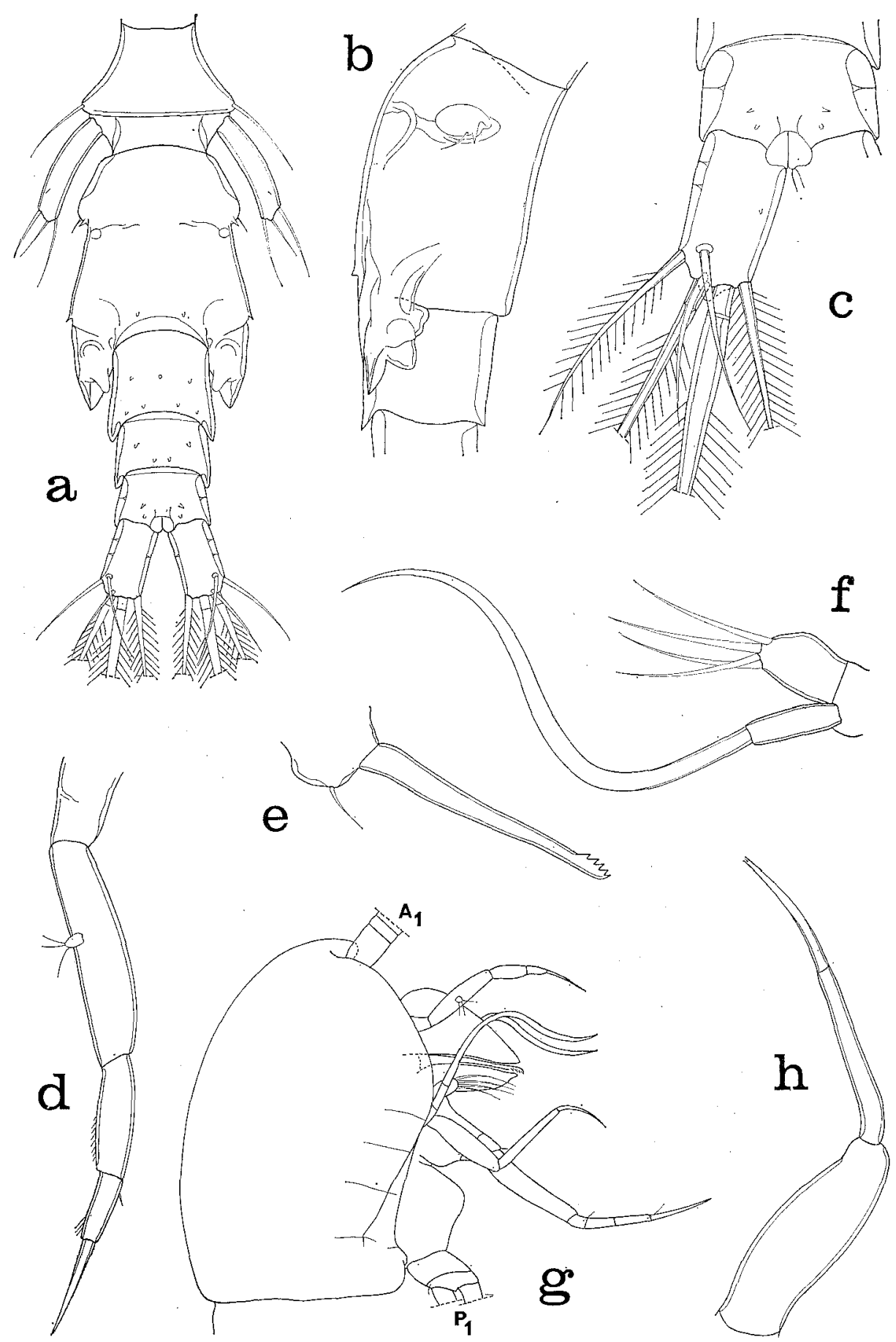

Fig. 21. Glyptocheres comanthinae, new genus, new species, female. a, urosome, dorsal (scale B); b, genital segment and first postgenital segment, lateral (F); c, anal segment and caudal ramus, dorsal (D); d, second antenna, anteroventral (D); e, mandible, anterior (D); f, first maxilla, outer (D), g, cephalosome, lateral (B); h, second maxilla, anterior (D). 

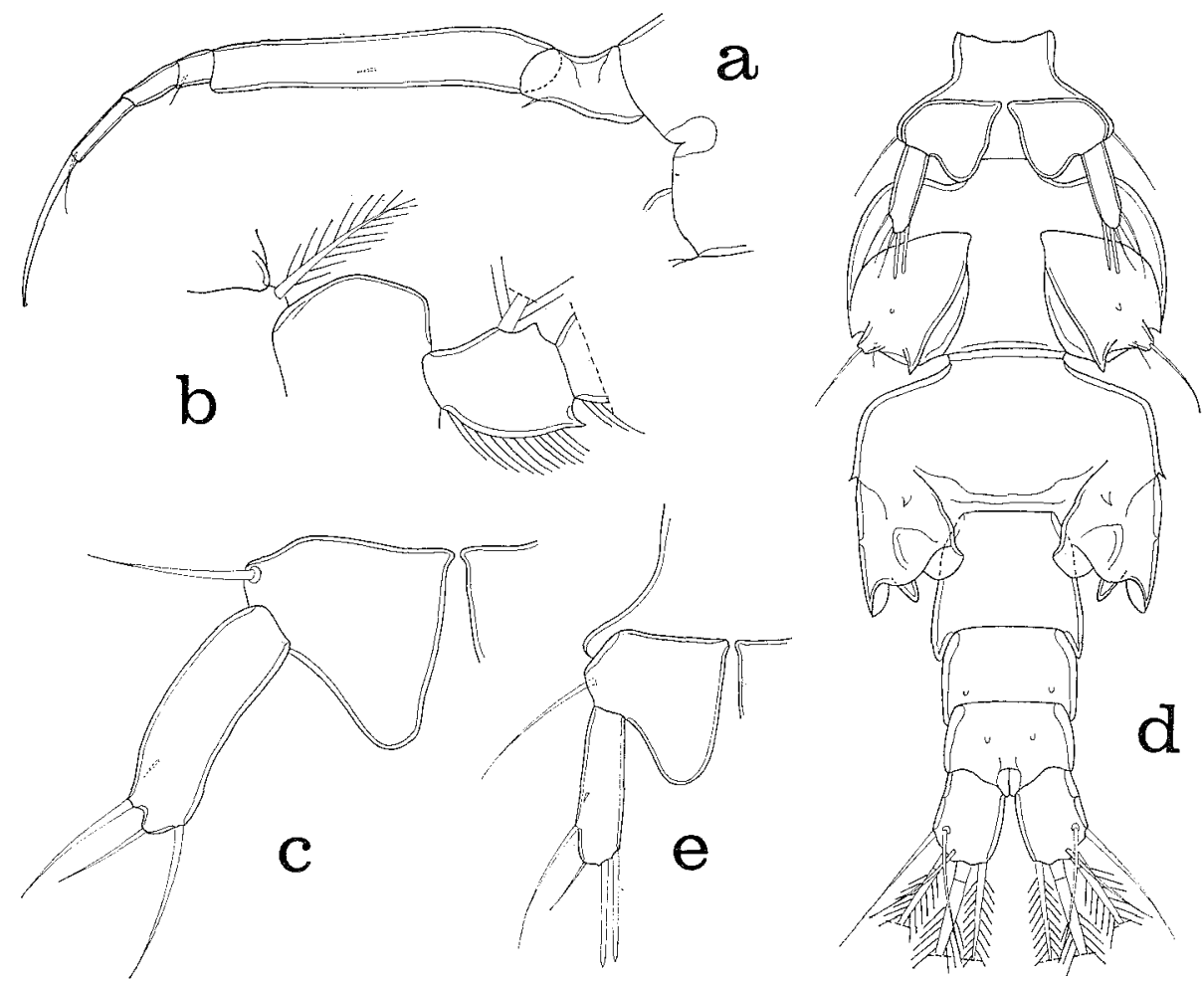

Fig. 22. Glyptocheres comanthinae, new genus, new species. Female. a, maxilliped, posterior (scale F); b, inner margin of basis of leg 1, anterior (D); c, leg 5, ventral (D). Male. d, urosome, ventral (F); e, leg 5 , ventral (D).

Caudal ramus similar to that of female but shorter, $23 \times 19 \mu \mathrm{m}$, ratio $1.21: 1$.

Rostral area as in female. First antenna with aesthete $44 \mu \mathrm{m}$, otherwise as in C. comanthiphilus. Second antenna, oral cone, mandible, first maxilla, second maxilla, maxilliped, and legs 1-4 as in female.

Leg 5 (Fig. 22e) with seta on first segment $26 \mu \mathrm{m}$. Second segment $29 \times 8$ $\mu \mathrm{m}$, its setae from outer to inner $3,24,10,20$, and $20 \mu \mathrm{m}$.

Leg 6 (Fig. 22d) usual flap on genital segment bearing spiniform process and 2 small setae.

Spermatophore not seen.

Color as in female.

Etymology. The specific name is the genitive form of the generic name of the host.

Remarks. Glyptocheres comanthinae may be distinguished from $G$. extrusus by several features as follows: (1) the caudal ramus of the female having the ratio $1.64: 1$ as opposed to $2.29: 1$, (2) the very long seta on the exopod of the first maxilla, 5.5 times longer than the exopod segment, and (3) the free segment of leg 5 having the ratio $3.03: 1$, instead of $8.56: 1$ as in C. extrusus. 
Order Poecilostomatoida Thore11, 1859

Family Pseudanthessiidae Humes \& Stock, 1972

Genus Pseudanthessius Claus, 1889

\section{Pseudanthessius comanthi Humes, 1972}

Material. From Comanthus bennetti (J. Müller). PHILIPPINES: 1399, 10, from 1 host, in 40 $\mathrm{m}$, Bohol Island, $10^{\circ} 17.9^{\prime} \mathrm{N}, 124^{\circ} 10.9^{\prime} \mathrm{E}, 22$ September 1975 , Thomas Forhan collector. MOLUCGAS: 83웅, 45 $\jmath^{\circ} \sigma^{\circ}$, from 1 host, in $2 \mathrm{~m}$, Poelau Marsegoe, $02^{\circ} 59^{\prime} 30^{\prime \prime} \mathrm{S}, 128^{\circ} 03^{\prime} 30^{\prime \prime} \mathrm{E}, 15$ May 1975 ; $1 \hat{\delta}$, from 1 host in $3 \mathrm{~m}$, southwestern shore of Goenoeng Api, Banda Islands, $04^{\circ} 31^{\prime} 45^{\prime \prime} \mathrm{S}, 129^{\circ} 51^{\prime}$ $55^{\prime \prime} \mathrm{E}$, 28 April 1975; 1 ㅇ, from 1 host, in $4 \mathrm{~m}$, same locality and date; 2 q $9,53 \jmath^{3}$, from 1 host, in $4 \mathrm{~m}$, same locality and date; 9 우, $5 \sigma^{\circ} \sigma^{\prime}$, from 1 host, in $10 \mathrm{~m}$, Poelau Gomumu, $01^{\circ} 50^{\prime} 00^{\prime \prime} \mathrm{S}, 127^{\circ} 30^{\prime} 54^{\prime \prime} \mathrm{E}$,

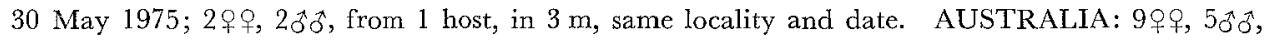
from 1 host, in $12 \mathrm{~m}$, Mermaid Cove, Lizard Island, Queensland, Australia (Great Barrier Reef), $14^{\circ}$ $39^{\prime} 50^{\prime \prime} \mathrm{S}, 145^{\circ} 27^{\prime} 00^{\prime \prime} \mathrm{E}, 26$ October 1982; 2 우, from 1 host, in $12 \mathrm{~m}$, Mermaid Cove, Lizard Island, 27 October 1982.

From Comanthus samoanus A.H. Clark: $1 \delta$, from 1 host, in $25 \mathrm{~m}$, southern shore of Goenoeng

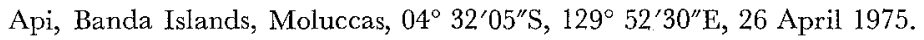

\section{Conclusions}

Although a relatively small number of collections of copepods from comasterid crinoids have been made, only 33 thus far from the vast area of the Indo-Pacific, information obtained allows a few observations to be made.

1) Comasterids in the area where collections were made (Enewetak, Philippines, Moluccas, northern Australia, Great Barrier Reef) nearly always have copepod associates.

2) Individuals of Comanthus bennetti in the Philippines, northern Australia, and the Moluccas, and Comanthus samoanus at Banda in the Moluccas, have three copepods associated with them: Pseudanthessius comanthi, Collocheres comanthiphilus, and Glyptocheres extrusus.

3) Individuals of Comanthus variabilis at Darwin, northern Australia, have two copepod associates: Collocheres marginatus and Collocheres thysanotus.

4) Comaster multibrachiatus may harbor at the same time both Collocheres inflatiseta and Collocheres parvus.

5) Three crinoids have only one copepod associate: Comaster gracilis with Collocheres titillator, Comantheria rotula with Collocheres serrulatus, and Comanthina schlegeli with Glyptocheres comanthinae.

6) Pseudanthessius comanthi is found on Comanthus bennetti at Enewetak in the Marshall Islands (see Humes, 1972), at Bohol in the Philippine, in the Moluccas (Poelau Gomumu, Poelau Marsegoe), and on the Great Barrier Reef, Australia (Lizard Island), and also occurs on Comanthus samoanus at Banda in the Moluccas.

7) Collocheres comanthiphilus occurs on Comanthus bennetti in the Philippines, at Lizard Island, Australia, and in the Moluccas; on Comanthus parvicirrus in New Caledonia; on Comanthus samoanus in the Moluccas and New Caledonia, and on Comanthus sp. in New Caledonia. 
8) Collocheres comanthiphilus is abundant on Comanthus bennetti (1,530 copepods including 835 우우 and 635 ơ from 14 hosts, with an average of 109 copepods per crinoid).

9) Glyptocheres extrusus is found in considerable numbers on Comanthus bennetti (760 copepods including 500 우 and $260 \hat{\partial}$ from 11 hosts, with an average of 70 copepods per crinoid).

List of crinoids and their associated copepods in the western Pacific

Comaster gracilis

Collocheres titillator

Moluccas

Comaster multibrachiatus

Collocheres inflatiseta

Moluccas

Collocheres parrus

Moluccas

Comantheria rotula

Collocheres serrulatus

Moluccas

Comanthina schlegeli

Glyptocheres comanthinae

Comanthina variabilis

Collocheres thysanotus

Collocheres marginatus

Comanthus bennetti

Collocheres comanthiphilus

Glyptocheres extrusus

Pseudanthessius comanthi

Moluccas

Northern Territory (Australia)

Northern Territory (Australia)

Philippines, Moluccas, Great

Barrier Reef (Australia)

Philippines, Moluccas, Great

Barrier Reef (Australia)

Enewetak Atoll, Philippines,

Moluccas, Great Barrier

Reef (Australia)

Comanthus briareus

Collocheres thysanotus

Northern Territory (Australia)

?Comanthus parvicirrus

Collocheres comanthiphilus

Comanthus samoanus

Collocheres comanthiphilus

Comanthus sp.

Collocheres comanthiphilus

New Caledonia

Moluccas, New Caledonia

New Caledonia

Copepods previously reported from crinoids both in the Mediterranean and in the Indo-Pacific

Siphonostomatoida:

Collocheres gracilicauda (Brady) (for references in the literature see Stock, 1966a, 
p. 236) from Antedon mediterranea Lamarck, Trieste, Italy (probably an accidental, isolated occurrence, since the copepod has never been rediscovered on Antedon although repeated searches have been made (according to Stock, 1960, p. 229; for the same opinion see Bresciani \& Lützen, 1962, p. 380); the copepod appears to be typically associated with the ophiuroid Ophiothrix.

Collocheres uncinatus Stock, 1966, from Heterometra savignyi (J. Müller) and Oligometra serripinna (P.H. Carpenter) at Eilat, Israel, Gulf of Aqaba (Stock, 1966a).

Collocheres inaequalis Ho, 1982, from Comanthus japonicus (J. Müller) at Shirogazaki near Tsukumo Bay, Japan (Ho, 1982). (The host is now Oxycomanthus japonicus according to Rowe et al. (1986).)

Cyclopoida:

Enterognathus comatulae Giesbrecht, 1900, from Antedon bifida (Pennant), A. rosacea (Linck), and $A$. mediterranea Lamarck in the Mediterranean and the British Isles (see Illg \& Dudley, 1980, p. 153).

Enterognathus lateripes Stock, 1966, from Heterometra savignyi (J. Müller), Oligometra serripinna (P.H. Carpenter), and Decametra chadwicki A.H. Clark at Eilat, Israel, Gulf of Aqaba (Stock, 1966b). For references to the literature on these two species see Illg \& Dudley (1980).

Doropygus pulex Thorell, from Antedon petasus, Gullmarfjord, Sweden (Barel \& Kramers, 1977, p. 75).

Poecilostomatoida:

Pseudanthessius madrasensis Reddiah, 1968, from unidentified crinoids (probably Tropiometra carinata (Lamarck) (see Humes \& Ho, 1970, p. 5), harbor of Madras, India (Reddiah, 1968). From Tropiometra carinata, vicinity of Nosy Bé, northwestern Madagascar (Humes \& Ho, 1970).

Pseudanthessius major Stock, 1967, from Heterometra savignyi and Lamprometra klunzingeri (Hartlaub), Eilat, Israel, Gulf of Aqaba (Stock, 1967a). From Cenometra emendatrix (Bell), Heterometra africana (A.H. Clark), Stephanometra indica (Smith), Lamprometra klunzingeri, Liparometra? sp., and Dichrometra sp. ? afra A.H. Clark, all from the vicinity of Nosy Bé, northwestern Madagascar (Humes \& Ho, 1970).

Pseudanthessius minor Stock, 1967, from Lamprometra klunzingeri, Eilat, Israel, Gulf of Aqaba (Stock, 1967a), from Heterometra africana, Lamprometra klunzingeri, Liparometra? sp., and Dichrometra sp. ? afra, all from the vicinity of Nosy Bé, northwestern Madagascar (Humes \& Ho, 1970).

Pseudanthessius angularis Humes and Ho, 1970, from Stephanometra indica (Smith) and Dichrometra sp. ? afra, from vicinity of Nosy Bé, northwestern Madagascar (Humes \& Ho, 1970).

Pseudanthessius rostellatus Humes and Ho, 1970, from Comaster sp. ? nov. aff. distinctus (P.H. Carpenter), Nosy Bé, northwestern Madagascar (Humes \& Ho, 1970).

Pseudanthessius comanthi Humes, 1972, from Comanthus bennetti (J. Müller), Enewetak Atoll, Marshall Islands (Humes, 1972). 
Scambicornus pillaii Stock, 1983, from Capillaster multiradiatus (Linnacus), Eilat, Israel, Gulf of Aqaba (Stock, 1983).

Kelleria gradata Stock, 1967, from Heterometra savignyi (J. Müller), Eilat, Israel, Gulf of Aqaba (Stock, 1967b).

Doridicola patulus (Humes, 1959), from Cenometra emendatrix (Bell), near Nosy Bé, northwestern Madagascar (Humes \& Stock, 1973, 1983).

Doridicola venustus (Humes, 1959), from Cenometra emendatrix, near Nosy Bé, northwestern Madagascar (Humes \& Stock, 1973).

Critomolgus fishelsoni (Stock, 1967), from Oligometra serripinna, Eilat, Israel (Gulf of Aqaba) (Stock, 1967b; Humes \& Stock, 1983).

\section{Acknowledgements}

I thank Thomas Forhan for collections made at Bohol Island in the Philippines, and Dr. Lyle Vail for collections at Darwin, Northern Territory, Australia.

The specimens from the Moluccas were collected by the author during the Alpha Helix East Asian Bioluminescence Expedition, which was supported by the National Science Foundation of the United States, under grants OFS 7401830 and OFS 7402888 to the Scripps Institution of Oceanography and grant BMS 7423242 to the University of California, Santa Barbara.

The New Caledonian material was collected with the support of a National Science Foundation grant, GB-8381X. The collection of the specimens from Lizard Island, Queensland, Great Barrier Reef, was made possible by another NSF grant, DEB 8016241.

I thank Dr. Lyle Vail, Northern Territory Museum, Darwin, Northern Territory, Australia, and Miss Ailsa M. Clark, British Museum (Natural History), London, England, for identifications of the crinoids. I also thank Dr. F.W.E. Rowe, Australian Museum, Sydney, Australia, for advice on the taxonomy of the comasterid crinoids.

This study was aided in part by a grant from the National Science Foundation (BSR-8514561).

\section{References}

Barel, C.D.N., \& P.G.N. Kramers. 1977. A survey of the echinoderm associates of the north-east Atlantic area. Zool. Verh., 156: 1-159.

Bresciani, J., \& J. Lützen. 1962. Parasitic copepods from the west coast of Sweden including some new or little known species. Vidensk. Medd. Dansk Naturh. Foren., 124: 367-408.

Clark, A.H. 1909. Revision of the crinoid family Comasteridae with descriptions of new genera and species. Proc. U.S. Nat. Mus., 36 (1685): 493-507.

- 1931. A monograph of the existing crinoids. I(3) Superfamily Comasterida. Bull. U.S. Nat. Mus., $82(3)$ : i-vii, 1-816.

Clark, A.M., \& F.W.E. Rowe. 1971. Shallow-water Indo-West Pacific echinoderms. British Museum (Natural History), London. Pp. i-vii, 1-238.

Ho, J.-S. 1982. Copepoda associated with echinoderms of the Sea of Japan. Ann. Rep. Sado Mar. Biol. Stat., Niigata Univ., 12: 33-61.

Hoggett, A.K. 1986. A reappraisal of the family Comasteridae A.H. Clark, 1908 (Echinodermata: Crinoidea), with the description of a new subfamily and a new genus. Zool. J. Linn. Soc., 88: 103-142.

Humes, A.G. 1972. Pseudanthessius comanthi n. sp. (Gopepoda, Cyclopoida) associated with a crinoid at Eniwetok Atoll. Pac. Sci., 26: 373-380.

- 1964. A method for studying the external anatomy of copepods. Crustaceana, 6: 238240. 
- 2 _ J.-S. Ho. 1970. Cyclopoid copepods of the genus Pseudanthessius associated with crinoids in Madagascar. Smithsonian Contr. Zool., 54: 1-20.

— , \& J.H. Stock. 1973. A revision of the family Lichomolgidae Kossmann, 1877, cyclopoid copepods mainly associated with marine invertebrates. Smithsonian Contr. Zool., 127: i-v, 1-368. - \& 1983. Redefinition of the genus Doridicola Leydig, 1852, synonymy of Metaxymolgus Humes \& Stock, 1972, and establishment of a new genus, Critomolgus (Copepoda, Poecilostomatoida, Lichomolgidae). Bull. Zool. Mus., Univ. Amsterdam, 9: 93-96.

Illg, P.L., \& P.L. Dudley. 1980. The family Asidicolidae and its subfamilies (Copepoda, Cyclopoida), with descriptions of new species. Mem. Mus. Nat. Hist. Nat., n. s., ser.A, Zool., 117: 1-192.

Reddiah, K. 1968. Two new Pseudanthessius species (Copepoda-Lichomolgidae) from the Madras Harbour. J. Mar. Biol. Assoc. India, 1966, 8: 320-328.

Rowe, F.W.E., A.K. Hoggett, R.A. Birtles, \& L.L. Vail. 1986. Revision of some comasterid genera from Australia (Echinodermata: Crinoidea), with descriptions of two new genera and nine new species. Zool. J. Linn. Soc., 86: 197-277.

Stock, J.H. 1960. Sur quelques Copépodes associés aux Invertebrés des côtes du Roussillon. Crustaceana, $1: 218-257$.

-1966a. On Collocheres Canu, 1893, and Leptomyzon Sars, 1915, two synonymous genera of Copepoda. Beaufortia, 13:221-239.

-1966b. Copepoda associated with invertebrates from the Gulf of Aqaba. 2. Enterognathus lateripes n. sp., a new endoparasite of Crinoida (Cyclopoida, Ascidicolidae). Proc. Koninkl. Nederl. Akad. Wetensch.-Amsterdam, ser. G, 69: 211-216.

- 1967a. Copepoda associated with invertebrates from the Gulf of Aqaba. 3. The genus Pseudanthessius Claus, 1889 (Cyclopoida, Lichomolgidae). Proc. Koninkl Nederl. Akad. Wetensch. -Amsterdam, ser. C, 70: 232-248.

- 1967b. Copepoda associated with invertebrates from the Gulf of Aqaba. 4. Two new Lichomolgidae associated with Crinoida. Proc. Koninkl. Nederl. Akad. Wetensch.-Amsterdam, ser. C, 70: 569-578.

ㄴ. 1983. A new species of Scambicornus (Copepoda, Gyclopoidea, Sabelliphilidae), associated with an unusual host, the crinoid Capillaster in the Red Sea. Selected Papers on Crustacea, pp. 1-10. Published by Dr. P. Rabindranath on behalf of Prof. N. Krishna Pillai Farewell Committee, The Aquarium, Trivandrum. 